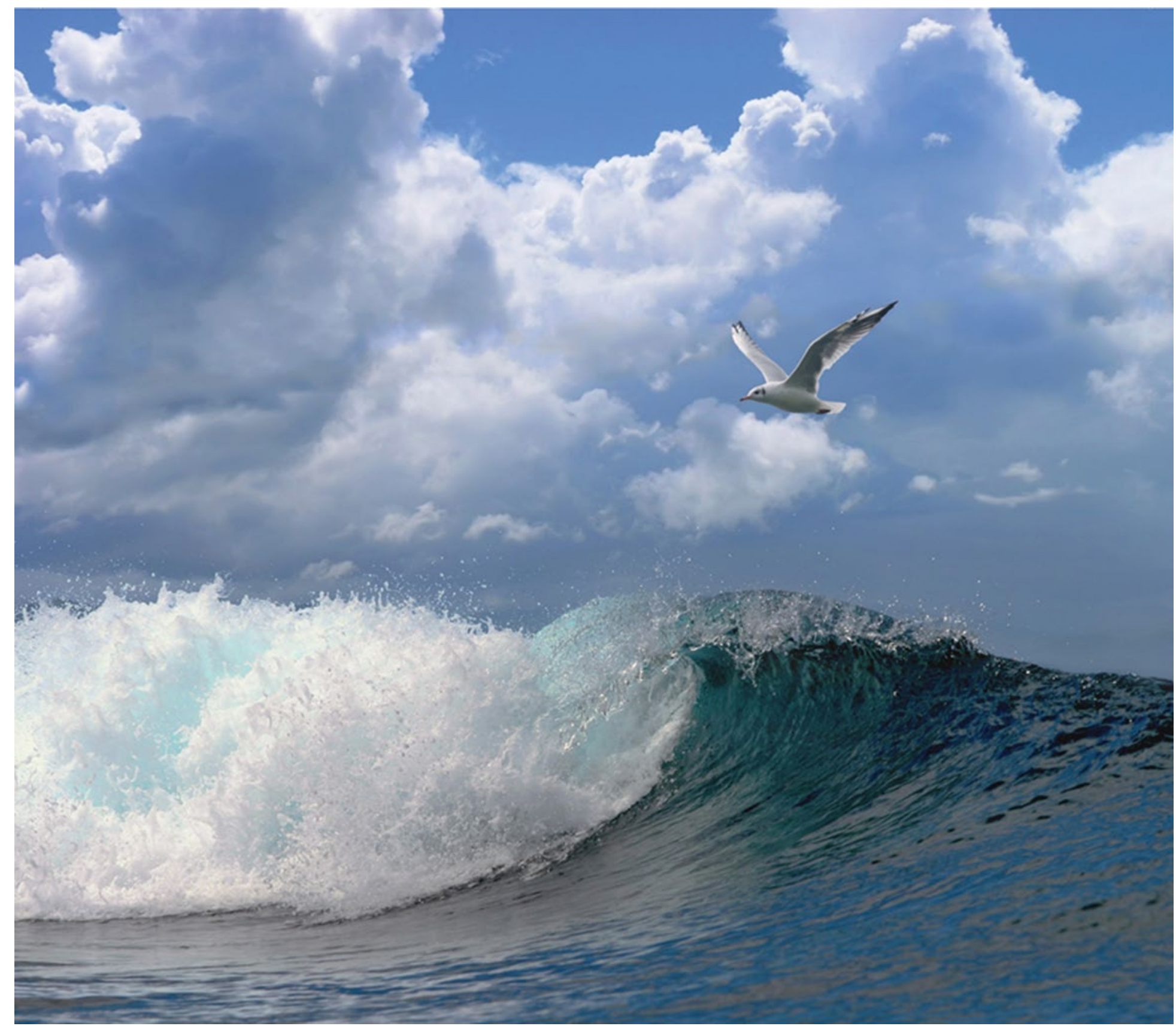

\title{
Monitoringsplan Vismigratie Nieuwe Waterweg regio
}




\section{Monitoringsplan vismigratie Nieuwe Waterweg regio}

Auteur(s): Winter, H.V.

Wageningen Marine Research, Wageningen University \& Research

RWS zaaknr. 31146695 (vallend onder RWS-DLO nr 31105620)

Wageningen Marine Research

IJmuiden, December 2019

VERTROUWELIJK Nee

Wageningen Marine Research rapport C128/19 
Keywords: Vismigratie, Onderzoeksopzet, Migratie knooppunten, Nieuwe Waterweg

Opdrachtgever: Rijkswaterstaat

T.a.v.: Nick Schoone

Steegoversloot 36

3311 PP Dordrecht

Dit rapport is gratis te downloaden van https://doi.org/10.18174/509318

Wageningen Marine Research verstrekt geen gedrukte exemplaren van rapporten.

Wageningen Marine Research is ISO 9001:2015 gecertificeerd.

\section{(c) Wageningen Marine Research}

Wageningen Marine Research, instituut binnen de rechtspersoon Stichting

Wageningen Research, hierbij vertegenwoordigd door Dr. M.C.Th. Scholten, Algemeen directeur

KvK nr. 09098104,

WMR BTW nr. NL 8113.83.696.B16.

Code BIC/SWIFT address: RABONL2U

IBAN code: NL 73 RABO 0373599285
Wageningen Marine Research aanvaardt geen aansprakelijkheid voor gevolgschade, noch voor schade welke voortvloeit uit toepassingen van de resultaten van werkzaamheden of andere gegevens verkregen van Wageningen Marine Research opdrachtgever vrijwaart Wageningen Marine Research van aanspraken van derden in verband met deze toepassing.

Alle rechten voorbehouden. Niets uit deze uitgave mag weergegeven en/of gepubliceerd worden, gefotokopieerd of op enige andere manier gebruikt worden zonder schriftelijke toestemming van de uitgever of auteur. 


\section{Inhoud}

$1 \quad$ Inleiding $\quad 4$

$2 \quad$ Afbakening monitoringsplan regio Nieuwe Waterweg $\quad 5$

2.1 Betrokken waterbeheerders en beheersgebieden $\quad 5$

2.2 Vismigratie principes en gebruikte terminologie 6

$3 \quad$ Kennis- en beheersvragen $\quad 8$

$4 \quad$ Monitoringsmethodieken $r$

4.1 Monitoringsmethodieken voor aanbod schattingen en bepaling van passage efficiëntie $\begin{array}{ll}\text { (algemeen) } & 10\end{array}$

4.2 Monitoringsmethodieken voor intrek onderzoek 10

4.3 Monitoringsmethodieken voor uittrek onderzoek 11

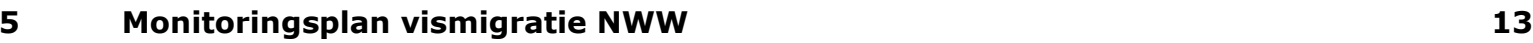

$5.1 \quad$ Voorstel opzet monitoring intrek 13

5.2 Voorstel opzet monitoring uittrek 14

5.3 Relatie met ander lopend onderzoek \& monitoring $\quad 16$

$6 \quad$ Aanbevelingen en overwegingen 18

$\begin{array}{llr}7 & \text { Kwaliteitsborging } & 19\end{array}$

$\begin{array}{lr}\text { Literatuur } & \mathbf{2 0}\end{array}$

$\begin{array}{lr}\text { Verantwoording } & 22\end{array}$

$\begin{array}{llr}\text { Bijlage } 1 & \text { Samenwerkingsverklaring } & 23\end{array}$

Bijlage 2 Inventarisatie beheersvragen en locaties (in- en uittrek-knooppunten) 24 


\section{Inleiding}

De Nieuwe Waterweg is één van de belangrijkste migratieroutes voor trekvis in Nederland, samen met het Haringvliet en de Afsluitdijk. Het geeft niet alleen toegang tot het hele achterland van het Rijn- en Maas stroomgebied voor vele trekvissoorten, maar ook tot veel poldergebieden rondom de Rijnmond. De waterbeheerders in de regio Nieuwe Waterweg en de Provincie Zuid-Holland zetten zich in voor een verbetering van de vismigratie tussen zee, rijkswater en polderwateren. De belangrijkste trekvissoorten hierbij zijn paling en driedoornige stekelbaars. Op 18 september 2017 werd de 'Samenwerkingsverklaring Routekaart voor Vismigratie en -Habitat rond de Nieuwe Waterweg' ondertekend, met de volgende doelstelling: "Rijkswaterstaat, de Provincie Zuid-Holland, de hoogheemraadschappen van Delfland en Schieland en de Krimpenerwaard en het waterschap Hollandse Delta zullen in 2017 onderzoeken welke mogelijkheden er zijn voor gezamenlijke inzet van menskracht en middelen (op te nemen in een plan van aanpak) zodat in 2018 gestart kan worden met een samenwerkingsproject Vismigratie en Habitat Nieuwe Waterweg." (zie bijlage 1).

De intrek en uittrek van vis, waarbij paling een belangrijke doelsoort is, in de beheersgebieden van de diverse waterbeheerders in de Nieuwe Waterweg regio hangt met elkaar samen. Door een integrale opzet van vismigratie monitoring op te zetten kunnen potentiële knelpunten, oplossingen, prioritering en evaluatie van maatregelen tot herstel van vismigratie integraal worden beschouwd en vindt er optimalisatie zowel inhoudelijk als budgettair plaats. Per waterbeheerder kan het verschillen of de nadruk op prioritering of evalueren ligt. Sommige waterbeheerders hebben na voorgaand onderzoek al geprioriteerd en weten al welke punten ze willen evalueren. Evaluatie van uitgevoerde maatregel is onze hoofdvraag en moet uit monitoring komen.

\section{Doelstelling}

Het opstellen van een modulair monitoringsprogramma rond de rijks-regio overgangen van de Nieuwe Waterweg en omliggende beheersgebieden. Via een inventarisatie bij de diverse waterbeheerders wordt een programma opgesteld met de wensen, eisen, en onderzoeksvragen rond het verbeteren van de intrek en uittrek van migrerende vis van elk van de waterbeheerders afzonderlijk, maar dat tevens resulteert in een samenhangend onderzoek en bijbehorende resultaten voor de geheel Waterweg regio.

De insteek van dit integraal monitoringsplan voor de gehele regio Nieuwe Waterweg is dat groepen vissen die het Nieuwe Waterweg systeem intrekken gevolgd worden van zee naar het achterland en onderweg verschillende beheersvragen beantwoorden voor de betrokken waterbeheerders. En andersom worden groepen vissen vanuit het achterland gevolgd op hun migratie naar zee, zodat ook stroomafwaartse beheersvragen op de routes van polder of boezem naar zee kunnen worden beantwoord. Door deze aanpak kunnen de beheersvragen kosten-effectief worden uitgevoerd (elke groep vissen beantwoordt meerdere vragen van meerdere beheerders onderweg). Door de gehele regio in een bepaald onderzoekjaar simultaan te bestrijken kunnen trajecten en knooppunten binnen de regio met elkaar worden vergeleken. Het intrekonderzoek en uittrekonderzoek kunnen onafhankelijk van elkaar worden uitgevoerd.

Deze aanpak is onlangs bijvoorbeeld succesvol uitgevoerd in de Noordzeekanaal regio voor de samenwerkende waterbeheerders, Rijkswaterstaat West- Nederland Noord, Hoogheemraadschap Hollands Noorderkwartier, Hoogheemraadschap van Rijnland, Waterschap Amstel, Gooi en Vecht, Provincie Noord-Holland, Sportvisserij Midwest Nederland, Port of Amsterdam, gemeente Amsterdam (Griffioen et al. 2019, Winter et al. 2019). 


\section{Afbakening monitoringsplan regio Nieuwe Waterweg}

\subsection{Betrokken waterbeheerders en beheersgebieden}

Het monitoringsplan in deze rapportage heeft betrekking op de beheersgebieden van de volgende waterbeheerders en overheden:

- $\quad$ Rijkswaterstaat West Nederland Zuid

- Hoogheemraadschap Delfland

- Waterschap Hollandse Delta

- Hoogheemraadschap van Schieland en de Krimpenerwaard

- Provincie Zuid-Holland

- (Hoogheemraadschap Rijnland)

In Figuur 2.1.1 zijn de belangrijkste hoofdwateren van het monitoringsgebied weergegeven. Het hart van de regio wordt gevormd door de Nieuwe Waterweg, Hartelkanaal, Nieuwe Maas, Oude Maas, Spui, Dordtsche Kil, Noord, westelijke deel van de Lek, zuidelijke deel van de Hollandse IJssel en de beheersgebieden van Hoogheemraadschap Delfland, Hoogheemraadschap Schieland en de Krimpenerwaard en het noordelijke deel van het beheersgebied Waterschap Hollandse Delta. Het Haringvliet, het Hollandsch Diep en de Amer zijn niet meegenomen in dit monitoringsplan evenals de meer stroomopwaartse delen van de rivieren Maas (Bergsche Maas) en Rijntakken (Beneden Merwede, Nieuwe Merwede). Het zuidoostelijke deel van het beheersgebied van Hoogheemraadschap Rijnland (gemaal Gouda) is optioneel ook meegenomen in dit plan, ook al maakt dit waterschap geen onderdeel uit van de samenwerkingsverklaring (zie Bijlage 1).

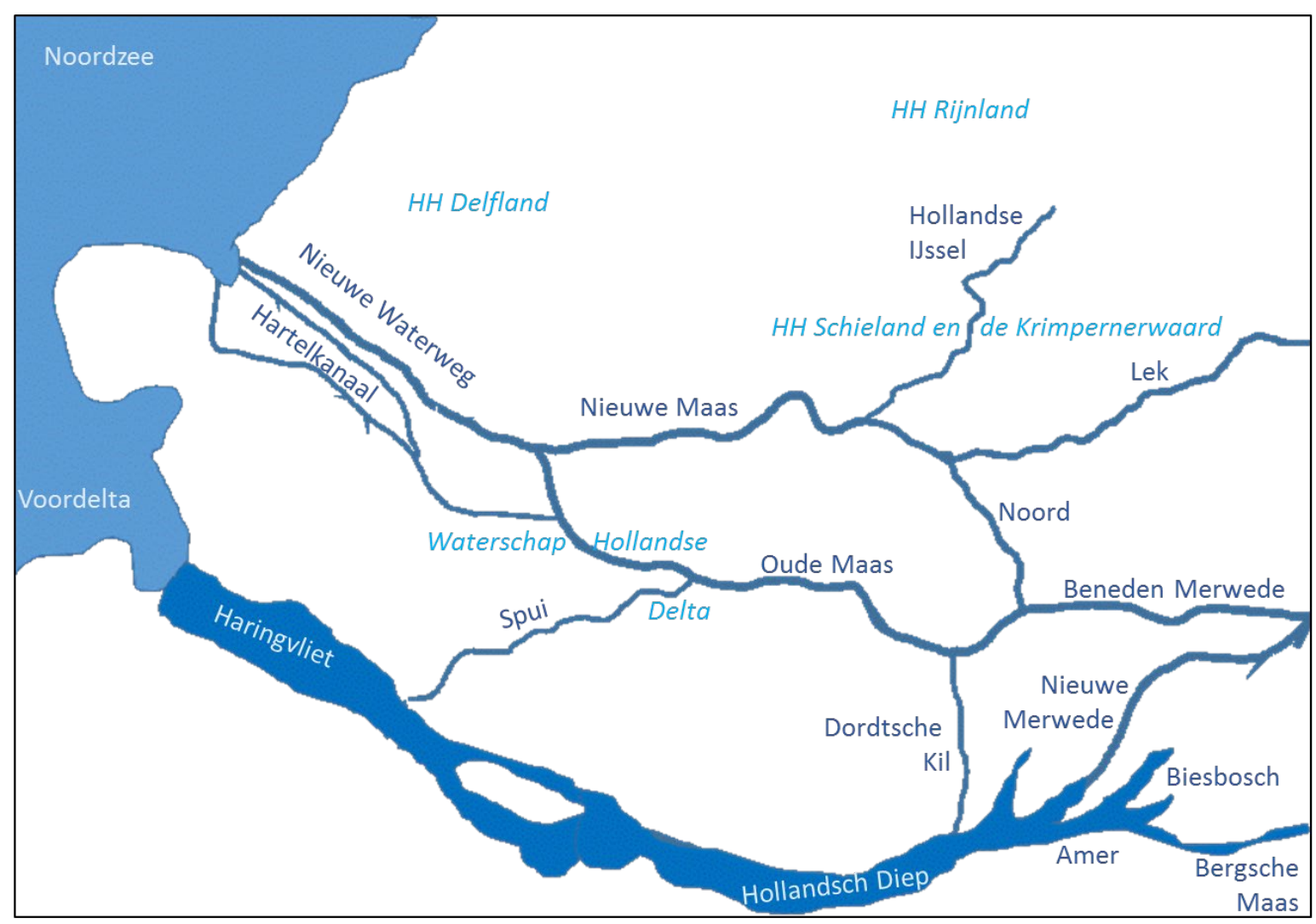

Figuur 2.1.1. Schematische kaart met de hoofdwateren en beheersgebieden van de waterschappen van de regio Nieuwe Waterweg waar dit monitoringsplan betrekking op heeft. 
Het netwerk van hoofdwatersystemen in het monitoringsgebied kent een zeer sterke dynamiek, zowel in stroming en getij (zie figuur 2.1.2) als in menselijke activiteiten zoals scheepvaart en met name het westelijke en centrale deel is een sterk door de mens beïnvloed stedelijk en industrieel gebied.

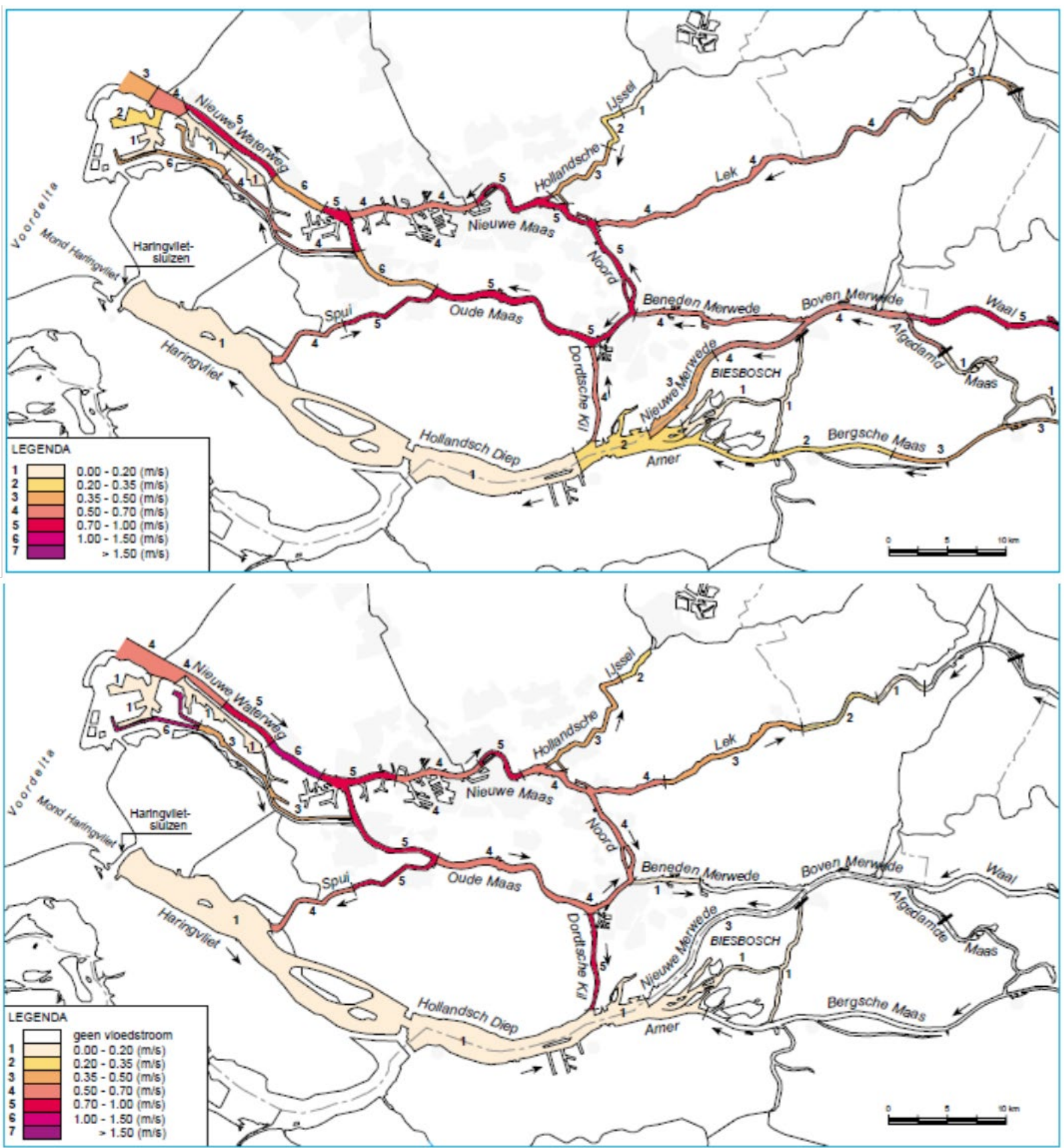

Figuur 2.1.2. Stromingsrichtingen en maximale stroomsnelheden tijdens vloed (boven) en tijdens eb (onder), (van Hees \& Peters, 1998 tijdens gemiddelde afvoer).

\subsection{Vismigratie principes en gebruikte terminologie}

Rond vismigratie in watersystemen worden veel termen en begrippen gebruikt. In onderstaand schema wordt kort weergeven welke opeenvolgende processen en begrippen in deze rapportage worden gehanteerd (figuur 2.2.1). Met name de term 'aanbod' geeft vaak aanleiding tot verwarring. In deze rapportage bedoelen we met aanbod, het totale aantal individuele vissen van een soort die tijdens een migratie-seizoen op een bepaalde plaats is aangekomen. Het aanbod op een bepaalde plaats vormt dus de optelsom van de nieuw aankomende individuen gedurende het hele migratieseizoen. De aantallen die op een bepaald moment ter plekke zijn (dit wordt ook vaak met 'aanbod' aangeduid), zijn de resultante van ter plaatse verblijvende individuen (met een bepaalde verblijftijd, 'ophoping'), succesvol 
doortrekkende individuen, onsuccesvol weer terugkerende en verder zoekende individuen en verliezen ter plaatse (bijvoorbeeld door predatie). Aanbod en efficiëntie zijn veel eenvoudiger vast te stellen voor soorten waarbij alle individuen gemotiveerd zijn om te migreren, zoals paling waarbij elke glasaal en schieraal moet migreren om bij te dragen aan de populatie. Voor zoetwatervissen als bijvoorbeeld brasem, snoekbaars en winde is dit veel lastiger omdat deze niet persé allemaal hoeve te migreren om hun levenscyclus te voltooien. Voor deze soorten wordt de daadwerkelijke passage efficiëntie vaak onderschat omdat in het aanbod ook niet-migrerende individuen kunnen zitten.

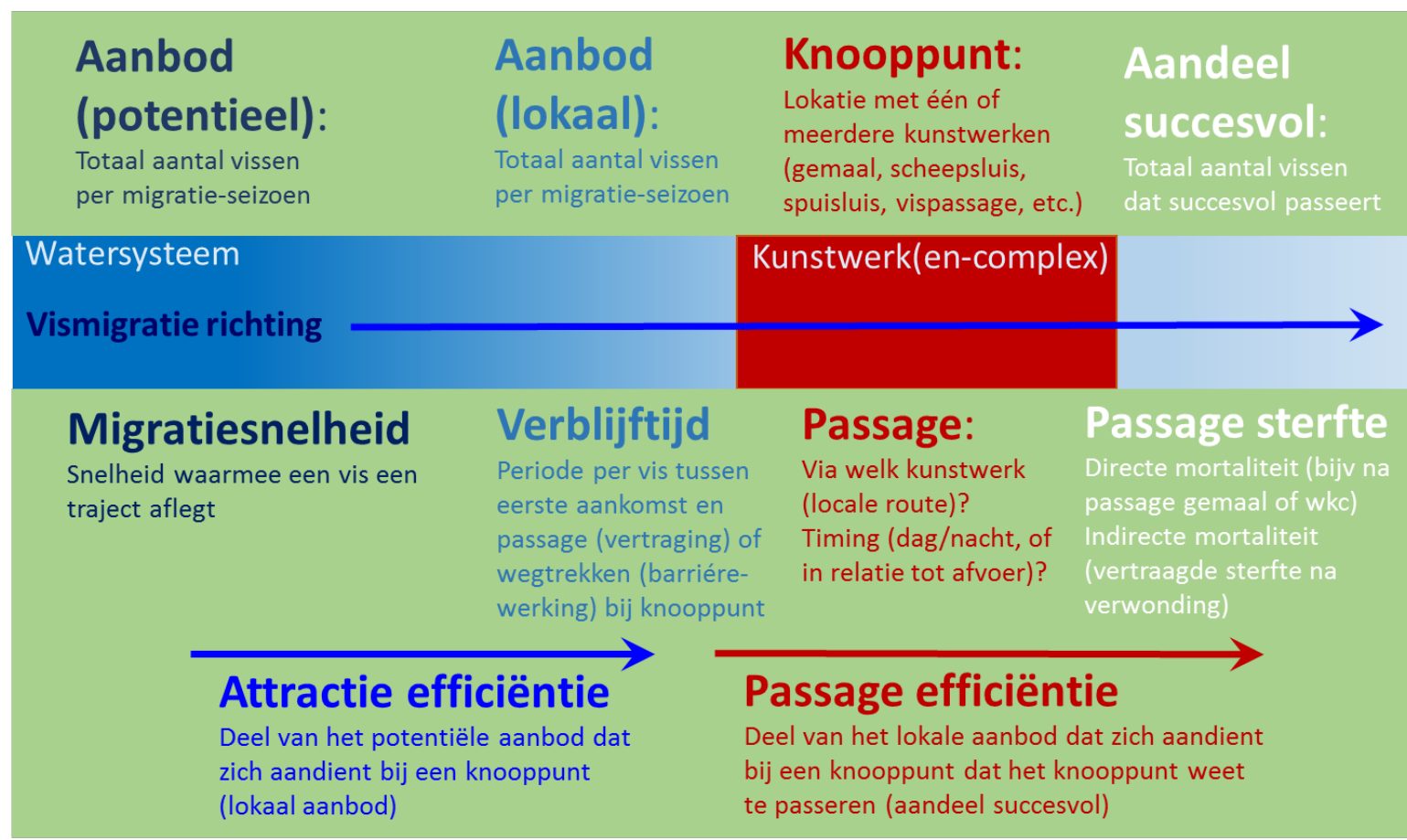

Figuur 2.2.1. Conceptueel schematisch overzicht van de opeenvolgende processen en begrippen tijdens vismigratie voor zowel intrek vanuit zee, als uittrek vanuit polder-/boezemsystemen, zoals in deze rapportage verder worden gehanteerd.

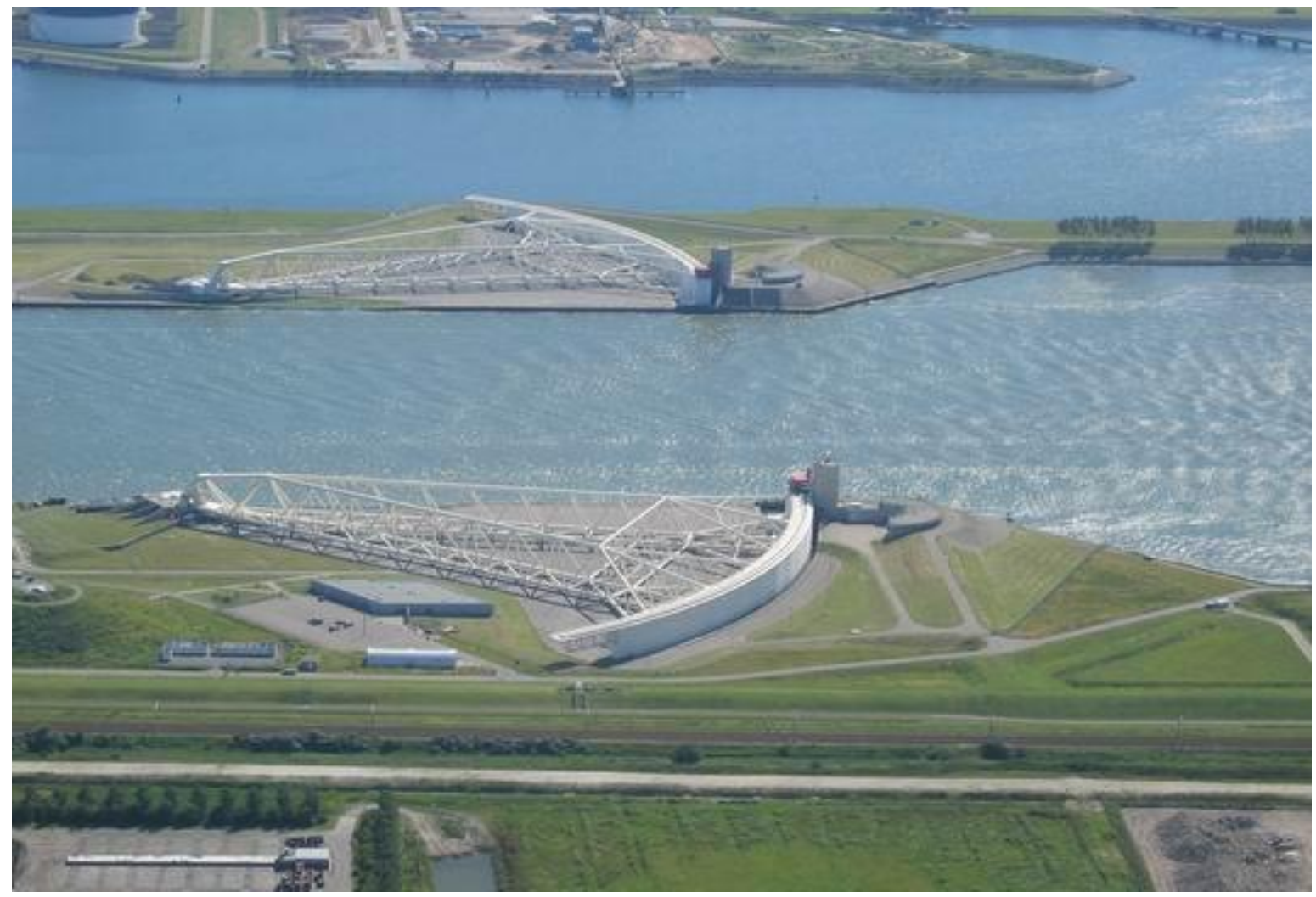

Nieuwe Waterweg bij Maeslantkering (Foto: https://beeldbank.rws.nl, Rijkswaterstaat) 


\section{Kennis- en beheersvragen}

Op basis van eerdere discussiestukken in het kader van vismigratie bijeenkomsten Rijn-West (onder begeleiding van Peter Phillipsen), vismigratieplannen in beheersgebieden (bijv. Spier et al. 2016), eerder uitgevoerde onderzoeken bij vispasssages en gemalen (voor de diverse waterschappen) en sluizen (bijv. de Bruijne et al. 2017), en kruisnetbemonsteringen (Projectgroep Samen voor de Aal, 2015, - 2018) zijn binnen deze rapportage werksessies die uitgevoerd in het eerste kwartaal van 2019 bij elk van de betrokken waterschappen, Rijkswaterstaat en Provincie Zuid-Holland (zie Bijlage 2). Uit deze sessies zijn onderstaande beheersvragen en daaraan gerelateerde onderzoeksvragen geïdentificeerd:

\section{Intrek van vis vanuit zee naar polderwateren}

De algemene onderzoeks- en beheersvragen worden geordend van intrek vanuit zee tot doortrek naar intrekpunten (knooppunten, meestal gemalen en/of sluizen, zie ook figuur 5.1.1) tot passage naar het achterland (boezem-/polderwateren). Al deze vragen gelden voor glasaal en waar deze eventueel ook voor driedoornige stekelbaars gelden is dat aangegeven met (3dst):

1) Hoeveel glasaal, trekt er de Nieuwe Waterweg in? (3dst?)

2) Wat is het aanbod aan glasaal per intrekpunt? (3dst) Als er in het onderzoekjaar ook kruisnetbemonsteringen worden uitgevoerd, kan de verhouding tussen kruisnettenvangst en onderliggend jaar worden uitgerekend. Deze locatie-specifieke verhouding kan dan worden gebruikt om ook voor andere jaren het aanbod uit de kruisnetvangsten uit te rekenen

3) Hoe verhoudt het lokale aanbod glasaal zich ten opzichte van de totale intrek in de Nieuwe Waterweg? Hoe is de verdeling van glasaal over de intrekpunten langs de Nieuwe Waterweg en de verschillende riviertakken? Speelt debiet (lokstroom) hierbij een rol, of afstand tot zee, of kenmerken van het intrekpunt (bijvoorbeeld luwten bij betreffende kunstwerken, of juist te veel stromingsdynamiek)? Trekken de meeste glasalen naar intrekpunten nabij de monding van de Nieuwe Waterweg of trekken de meesten via de riviertakken stroomopwaarts van de Nieuwe Waterweg regio?

4) Wat is de verblijftijd van glasaal bij een intrekpunt (gemaal, sluis)? (3dst)

5) Wat is de passage efficiëntie van glasaal via gerealiseerde migratievoorzieningen/maatregelen (vispassage, visvriendelijk sluisbeheer)? (3dst) Welk deel van het aanbod trekt succesvol binnen? Evalueren van genomen maatregelen of gerealiseerde vispassage faciliteiten.

6) Bij welke knooppunten vinden nog knelpunten in de intrek plaats? Met welke maatregelen zouden deze opgelost kunnen worden? En hoe zouden deze potentiële maatregelen geprioriteerd kunnen worden?

\section{Uittrek van vis vanuit polder- en boezemwateren naar zee}

De algemene onderzoeks- en beheersvragen worden geordend van uittrek vanuit het achterland (polder/boezemwateren), via passage van de uittrekpunten (knooppunten) tot het bereiken van de zee. Gezien de geringe grootte van uittrekkende driedoornige stekelbaars lijkt deze met slechts geringe verliezen via gemalen en spuisluizen naar de rijkswateren en zee te kunnen trekken. Er is desalniettemin weinig bekend over de uittrek van driedoornige stekelbaars en of hier eventueel beperkingen optreden. Omdat de potentiële problemen voor schieraal, gezien hun grotere lengte veel ernstiger zijn, zijn de onderstaande onderzoeksvragen met name op schieraal gericht. Andere zoetwatervissoorten die tussen polder-/boezem wateren en rijkswateren migreren kunnen eventueel ook worden onderzocht op onderstaande vragen. Alleen is voor deze soorten op voorhand niet duidelijk welk deel van de individuen gemotiveerd is om te migreren, hetgeen er in de praktijk vaak op neer komt dat er grotere aantallen gemerkte vissen nodig zijn om voldoende passage pogingen meetbaar te krijgen. Wel hebben de waterbeheerder hun maatregelen meestal niet alleen gericht op aal maar op meerdere doelsoorten (meerdere trekvissen en zoetwatervissen) en is het streven dat alle vissen die willen migreren kunnen migreren. Er zullen altijd soort-specifieke verschillen vorkomen in de mate waarin oplossingen werken, 
maar we gaan er vanuit dat als trekvissen zoals paling kunnen passeren de oplossing ook geschikt is voor de andere vissen. Het uittrek onderzoek richt zich daarom op paling:

7) Wat is de aantrekkingskracht van een knooppunt op schieraal ('attractie-efficiëntie')? Speelt debiet (lokstroom) hierbij een rol of zijn er andere factoren die hier belangrijk voor zijn?

8) Wat is de verblijftijd ('vertraging') en ruimtelijk zoekgedrag bij knooppunten tijdens de uittrek naar zee?

9) Wat is de passage efficiëntie van schieraal bij uittrek-knooppunten?

10) Hoe groot zijn eventuele verliezen bij passage van gemalen?

11) Wat is de timing van passage van een knooppunt (dag/nacht, in relatie tot uitgeslagen debiet, en werking in de tijd, van een gemaal of spuisluis en/of schuttingen van sluizen)?

12) Hoe kunnen bemalingsregime en schuttingen beheer worden geoptimaliseerd voor uittrek van schieraal?

13) Zijn er verliezen door menselijk handelen in trajecten zonder knooppunten, bijvoorbeeld door visserij of scheepvaart en natuurlijke predatie?

14) Welk deel van de schieraal die in het achterland vertrekt haalt succesvol de zee en via welke route?

15) Bij welke knooppunten vinden nog knelpunten in de intrek plaats? Met welke maatregelen zouden deze opgelost kunnen worden? En hoe zouden deze potentiële maatregelen geprioriteerd kunnen worden?

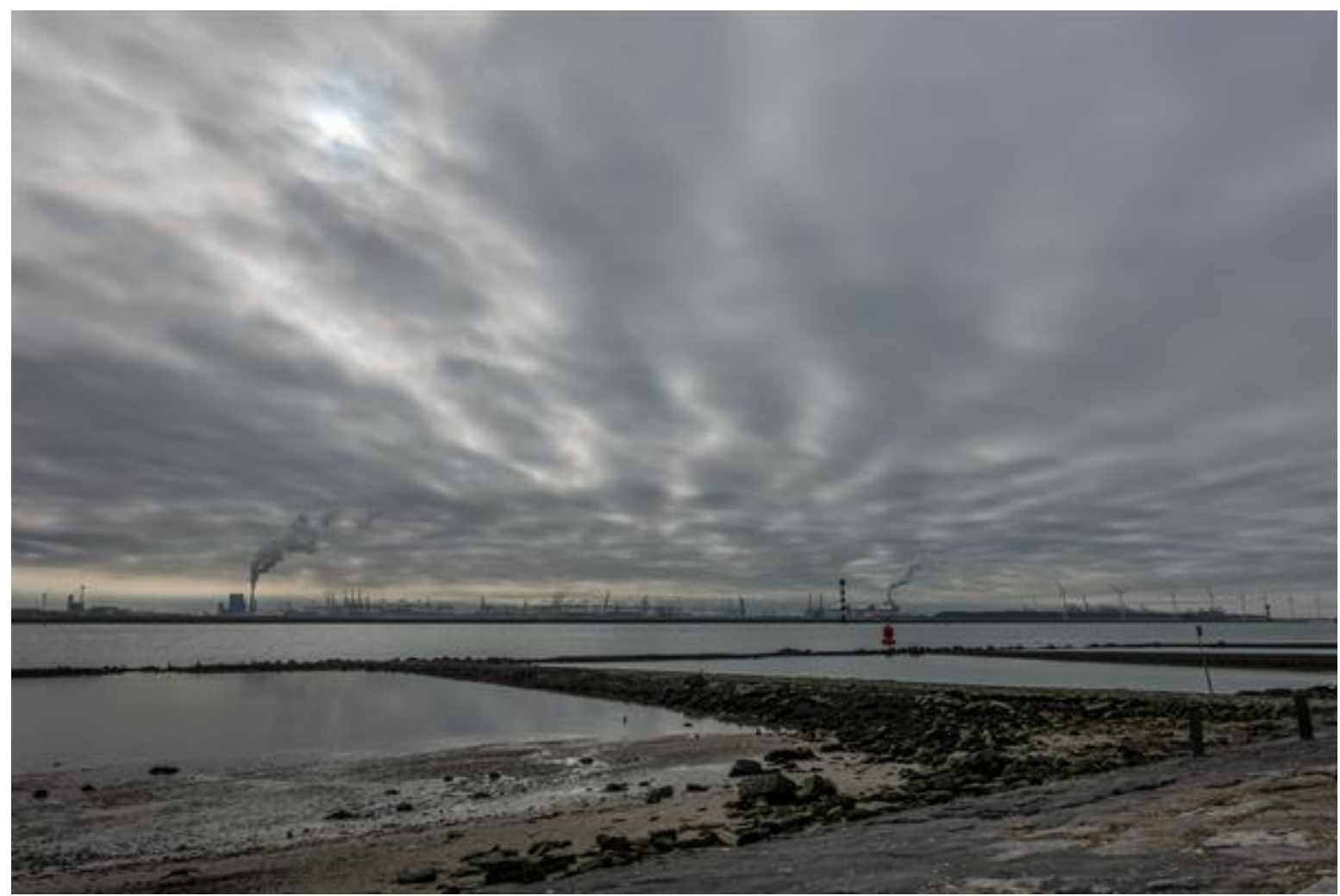

Nieuwe Waterweg bij Hoek van Holland (Foto: Harry van Reeken, https://beeldbank.rws.nl, Rijkswaterstaat) 


\section{Monitoringsmethodieken}

\subsection{Monitoringsmethodieken voor aanbod schattingen en bepaling van passage efficiëntie (algemeen)}

Het aanbod van in- of uittrekkende vissen op een locatie is moeilijk te bepalen. De meest geschikte methode hiervoor is met merk-terugvangst-experimenten. Hierbij worden groepen trekvissen gemerkt, die zich vervolgens mengen onder de andere niet gemerkte trekvissen. Tijdens terugvangst-acties kan uit de verhouding tussen gemerkte/niet-gemerkte trekvis het totale aanbod worden berekend. Ook kan uit merk-terugvangst experimenten de verblijftijd van vis bij kunstwerken worden bepaald.

Efficiëntie (zowel attractie als passage efficiëntie) kan zowel direct worden bepaald door het volgen van individuen, hoe meer individuen hoe nauwkeuriger de schatting. Dit volgen kan met verschillende zendertechnieken (allen beschikbaar voor grotere vissen, niet voor glasaal bijvoorbeeld) in combinatie met een netwerk aan ontvangststations. Maar het kan ook indirect worden bepaald wanneer het totale aanbod meetbaar is gemaakt in combinatie met een bepaling van alle vis die succesvol weet te passeren (bijvoorbeeld in een permanente (gedurende de migratieperiode) vangstopstelling die een vispassage volledig afdekt. De verhouding tussen het aantal succesvolle passanten en het totale aanbod voor het knooppunt is de passage efficiëntie. Deze methodieken moeten veelal toegepast worden voor kleinere vissen, waarvoor geen directe methodieken voorhanden zijn (zie ook Griffioen \& Winter 2017).

\subsection{Monitoringsmethodieken voor intrek onderzoek}

Om glasalen en driedoornige stekelbaars te vangen voor aanbodstudies zijn verschillende technieken beschikbaar (zie 4.1): veel gebruikt zijn kruisnetten en meer recentelijk ook glasaal-collectoren (ontwikkeld door Visserij Service Nederland en Waardenburg). Kruisnetten zijn eenvoudig in te zetten en er zijn vele vrijwilligersbemonsteringen. Het is intensief en de vangsten zijn doorgaans niet groot genoeg voor een betrouwbaar merk-terug vangst experiment. Wanneer ze minder frequent worden ingezet is de kans dat migratiepieken wordt gemist aanzienlijk. Glasaaldetectoren vissen continu en vangen grotere hoeveelheden glasaal (zie onder andere Griffioen et al. 2019) en zijn geschikter om tot betrouwbare resultaten te komen. Een combinatie van beide is het beste. Dit maakt de terugvangstkansen nog groter en maakt het daarnaast ook mogelijk om beide methoden via het onderliggende aanbod in elkaar om te rekenen, waardoor ook in jaren met alleen kruisnetbemonsteringen aanbod schattingen kunnen worden berekend (mits de migratiemogelijkheden bij het knooppunt gelijk blijven).

Voor het individueel merken van kleine vis zoals glasaal en driedoornige stekelbaars zijn nauwelijks methoden beschikbaar. Stekelbaarzen zijn succesvol gemerkt met PIT-tags, al is het op de grens, maar voor glasaal zijn nog geen goede individuele merkmethoden beschikbaar. Visible Implantable Elastomer (VIE) is een groepsmerk (een groep individuen die op dezelfde plaats is gevangen en weer uitgezet hebben een unieke kleur-code, maar niet elk individu binnen de groep heeft een unieke code) dat de afgelopen jaren succesvol is toegepast in glasaal door RAVON (Gemaal Schouten in Scheveningen in 2017; Griffioen et al. 2018; en meer recentelijk bijvoorbeeld in Zeeland) en door WMR (in Noordzeekanaal voor zowel glasaal als driedoornige stekelbaars Griffioen et al. 2019; en langs de Nederlandse kust op 5 grote intrekpunten in 2019). Het staat toe dat er vele verschillende groepen kunnen worden geïdentificeerd, en ze zijn met een UV lamp in het donker zeer opvallend lichtgevend en daardoor zijn gemerkte glasalen en driedoornige stekelbaarzen eenvoudig te vinden, ook tussen grote vangsten (zie foto's hieronder). 

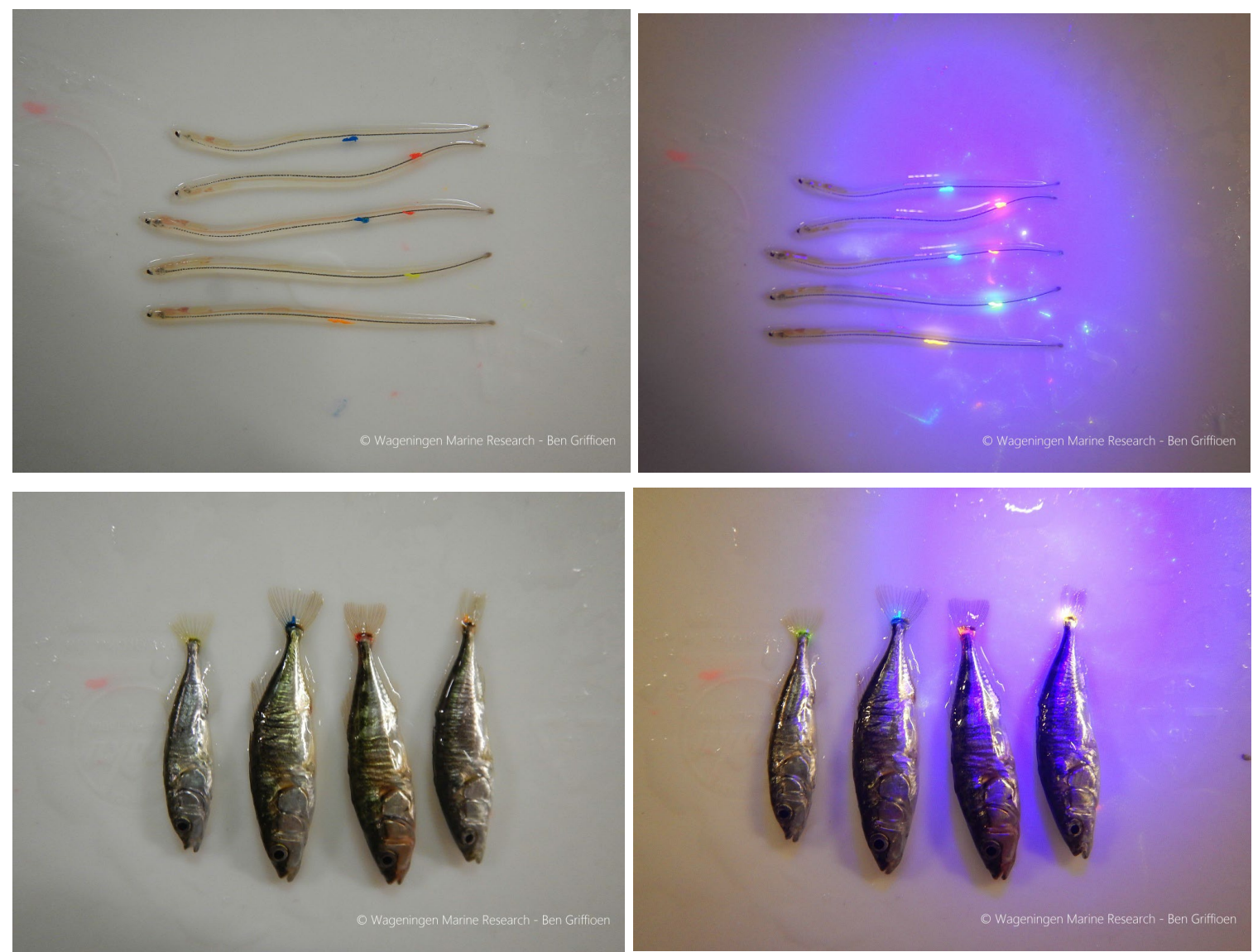

Figuur 4.1 De verschillende kleuren VIE-tags onder lichte omstandigheden (links) en onder violet licht, waarbij fluorescentie optreedt ${ }^{1}$ (rechts) in glasaal (boven) en driedoornige stekelbaars (onder).

\subsection{Monitoringsmethodieken voor uittrek onderzoek}

Voor het merken van vis zijn vele methodieken beschikbaar in twee categorieën: individuele merken en groepsmerken. Hoe groter de vis hoe meer technieken er beschikbaar zijn. Hiervoor kunnen zendertechnieken worden ingezet waar bij een in de vis aangebracht zendertje een unieke code uitzendt naar een detectiestation, -antenne of ontvanger. Voor schieraal zijn in Nederland met name drie technieken toegepast:

1) het NEDAP trail transponder zendersystem in combinatie met een netwerk aan detectiestations die de volledige breedte van een watersysteem afdekken (permanent netwerk in beheer van RWS, André Breukelaar, zie Brevé et al. 2018); deze zenders zijn relatief groot, hebben een bereik van ca $15 \mathrm{~m}$ boven de antenne-loop die de gehele breedte van de watergang afdekt. De batterijen van de zenders (transponders) die voor schieraal zijn gebruikt gaan 2 jaar mee. $\mathrm{Er}$ liggen al enkele detectiestations inde Nieuwe Waterweg regio in de rijkswateren. Deze techniek is o.a. gebruikt voor schieraalonderzoek in de Maas (Winter et al. 2016, Winter et al. 2017, Jansen et al. 2017)

2) VEMCO akoestische telemetrie; hiervoor wordt vaak een tijdelijk netwerk met ontvangers (detectie range varieert van $150 \mathrm{~m}$ tot $>800 \mathrm{~m}$ afhankelijk van het type zender dat wordt gebruikt) voor de duur van een studie ingezet, maar er zijn ook permanente netwerken in bijvoorbeeld Westerschelde en de Belgische Noordzee (. Deze techniek is bijvoorbeeld succesvol ingezet bij het integrale vismigratie-onderzoek in de Noordzeekanaal regio, incl. Markermeer (Winter et al. 2019), bij gemalen onderzoek in Friesland en Groningen (van Keeken et al. 2013, Winter et al. 2016), en in Belgische rivieren en kanaalsystemen (Verhelst et al. 2018a, - 2018b, - 2018c, - 2018d). De levensduur van de zendertjes hangt af van het type zender en met welk tijdinterval deze uitzendt. Voor schieraal worden meestal V9 zenders met 0,8-2 jaar levensduur gebruikt.

\footnotetext{
${ }^{1}$ http://www.nmt.us/wp-content/uploads/2017/11/Using-the-VI-Light.pdf
} 
3) PIT-tag systemen; deze kleine transponders hebben geen batterij en daardoor onbeperkte levensduur, maar de detectie range van detectie-antennes is gering (meestal $<1 \mathrm{~m}$ ) en daardoor zijn grotere natte oppervlakten moeilijk af te dekken met deze techniek. Deze wordt voornamelijk toegepast in vispassage onderzoek, in rinketten in sluizen en met merkterugvangst experimenten met hand-held detectoren en het checken van vangsten (Griffioen \& Winter, 2018; Winter et al. 2019).

In de Nieuwe Waterweg regio is een NEDAP trail netwerk aanwezig. Echter om groepen gezenderde schieralen vanuit het achterland uit de polder-/boezemsystemen langs uittrekknooppunten in de regio te volgen zijn extra detectiestations nodig (minimaal 3 per uittrek-knooppunt; 1 aan weerzijden van de uitzetplek van gezenderde schieralen in het achterland van het uittrekpunt om te bepalen welk deel naar het gemaal/sluis toezwemt, en welk deel dieper het achterland intrekt; en 1 station direct benedenstrooms van het uittrekpunt om de passage efficiëntie te bepalen). Dit kan eenvoudiger en goedkoper worden gerealiseerd met behulp van VEMCO akoestische telemetrie dan met de veel duurdere en bewerkelijkere aanleg van extra NEDAP-stations. Hierbij zijn de VEMCO detectiestations ook veel flexibeler in te zetten. In de rijkswateren in de Nieuwe Waterweg regio zal dan een tijdelijk basisnetwerk aan detectiestations moeten worden geïnstalleerd. Bijkomend voordeel is dat ook in het Belgische deel van de Noordzee een VEMCO detectienetwerk operationeel is, wat voor aanvullende detecties van uit de NWW regio trekkende schieralen kan zorgen (zoals ook voor de Noordzeekanaal studies is waargenomen, Winter et al. 2019). De zenderonderzoeken leveren gegevens over vertraging, zoekgedrag, gevolgde routes bij complexen met kunstwerken (bijv. gemaal+schutsluis), en uittrek succes naar zee. In de analyse kunnen bekende sterftepercentages van schieraal in gemalen (verkregen via netbemonsteringen) mee worden genomen in de analyse van het deel dat via een gemaal migreert.

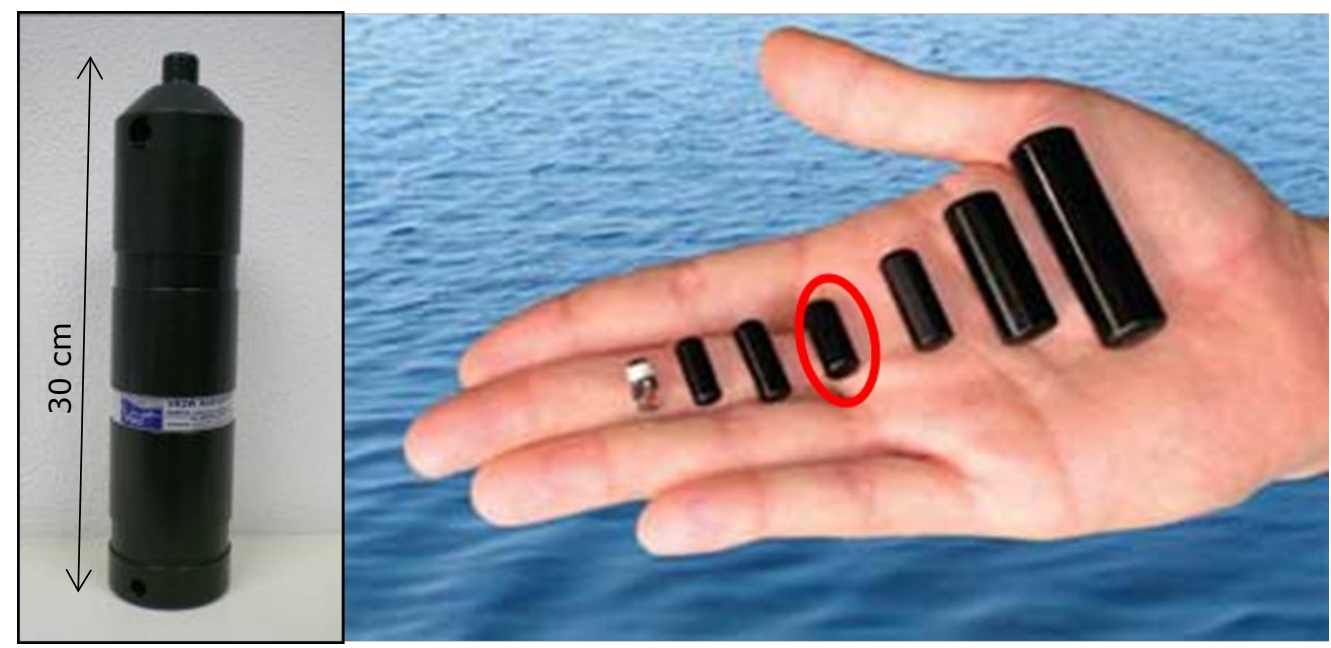

Figuur 4.2.1. Vemco VR2W ontvanger/receiver (links) en Vemco akoestische zenders/transmitters, waarbij de in deze studie voorgestelde V9 is omcirkeld (rechts)

Optioneel kan er op sommige locaties waar vispassages of migratievoorzieningen langs sluizen of gemalen zijn, voorzien worden met PIT antenne loops. De detectierange van VEMCO ontvangers is te groot om goed onderscheid te kunnen maken tussen routes via gemaal of via een vispassage. Wanneer het om kleine natte oppervlakten gaat, zijn deze met antennes af te dekken. Elke gezenderde aal kan naast een VEMCO-zender ook een PIT tag krijgen (die slechts 2 euro per stuk zijn, door het ontbreken van een batterij onbeperkte levensduur hebben, en zeer klein van formaat zijn, 'no regret' toevoeging) en zodoende kan ook het gebruik van deze bypasses door schieraal meetbaar worden gemaakt. Tot nu toe hebben andere onderzoeken in stroomafwaartse richting laten zien dat schieralen deze alternatieven niet of slechts in geringe mate gebruiken (Griffioen et al. 2019, Winter et al. 2019).

In sluizen kunnen rinketten met PIT-loops worden afgedekt om migratie middels visvriendelijk sluisbeheer meetbaar te maken, maar de schuttingen kunnen niet worden afgedekt middels PIT detectieantennes en passage met schuttingen mee worden derhalve gemist met PIT-tags. 


\section{Monitoringsplan vismigratie NWW}

De insteek van dit integraal monitoringsplan voor de gehele regio Nieuwe Waterweg is dat groepen vissen die het systeem intrekken gevolgd worden van zee naar het achterland en onderweg beheersvragen beantwoorden voor de verschillende waterbeheerders. En andersom worden groepen vissen vanuit het achterland gevolgd op hun migratie naar zee, zodat ook stroomafwaartse beheersvragen op de routes van polder/boezem naar zee kunnen worden beantwoord. Door deze aanpak kunnen de beheersvragen kosten-effectief worden uitgevoerd (elke groep vissen beantwoordt meerdere vragen onderweg). Door de gehele onderzoek-regio in een bepaald onderzoekjaar simultaan te bestrijken kunnen trajecten en knooppunten binnen de regio met elkaar worden vergeleken. Het intrekonderzoek en uittrekonderzoek kunnen wel onafhankelijk van elkaar worden uitgevoerd.

\subsection{Voorstel opzet monitoring intrek}

Voor het intrekonderzoek worden groepen met VIE tags gemerkte glasaal in de monding van de Nieuwe Waterweg uitgezet. Deze mengen zich onder de intrekkende glasaal. Uit de verhouding van de aantallen teruggevangen in de monding van de NWW gemerkte glasalen en de ongemerkte glasalen in het achterland is de populatie-omvang van intrekkende glasaal terug te berekenen (Griffioen et al. 2019). Het vangen van voldoende glasaal in de open vrij toegankelijke monding van de Nieuwe Waterweg is zeer waarschijnlijk praktisch niet haalbaar, anders dan bij zout-zout overgangen waar barrières zijn en ophoping van glasaal plaats vindt. Daarom wordt voorgesteld om hiervoor glasaal te gebruiken die op een andere locatie is gevangen, bijvoorbeeld Den Oever of Katwijk waar in eerdere onderzoeken grote aantallen glasaal gevangen konden worden. We weten uiteraard het aanbod niet bij de Nieuwe Waterweg. Maar er zijn ervaringen bij IJmuiden opgedaan. Daar waren 2000 glasalen aan de buitenzijde waren gemerkt. Deze leverden voldoende terugmeldingen in het achterland open tot een populatie schatting van ca 10 miljoen glasaal die het Noordzeekanaal intrekt. Op basis hiervan is de inschatting dat voor de Nieuwe Waterweg 4000 gemerkte glasalen uitzetten voldoende is. Deze zouden in meerdere batches van bijvoorbeeld 4×1000 glasalen verdeeld over het eerste deel van het intrekseizoen (februari/maart $\mathrm{t} / \mathrm{m} \mathrm{mei} / \mathrm{juni}$ ) worden uitgezet.

In het achterland van de Nieuwe Waterweg regio wordt intrekonderzoek gedaan bij geselecteerde intrekknooppunten. Hierbij zijn in principe twee mogelijkheden:

- Intrek-locaties waar een aanbodschatting wordt gedaan van glasaal en eventueel, mits lokaal kan worden gevangen ook voor driedoornige stekelbaars, en waar de gemiddelde verblijftijd voor het intrekpunt wordt bepaald

- Intrek-locaties waar naast bovenstaande, ook de intrekefficiëntie van glasaal en eventueel driedoornige stekelbaars via een vispassage of intrekvoorziening wordt bepaald.

De schattingen van het lokale aanbod en de gemiddelde verblijftijd worden per locatie uitgevoerd met een glasaaldetector, liefst in combinatie met kruisnetbemonsteringen, en het lokaal merken van groepen glasaal en driedoornige stekelbaars met VIE-tag.

De glasaaldetector, en kruisnet, vangen:

- Aantallen glasalen in de tijd (timing intrek tijdens het voorjaar)

- Leveren glasalen die gemerkt kunnen worden met VIE tags voor lokale aanbodschatting

- Terugvangsten van bij de NWW gemerkte glasalen (aanbod totale intrek in NWW)

- Terugvangsten van lokaal gemerkte glasalen (lokale aanbod schatting)

- Terugvangsten van glasalen gemerkt bij andere intreklocaties (zoekgedrag tussen locaties)

- Verblijftijd van glasaal bij de intreklocatie

- In kruisnetten wordt ook driedoornige stekelbaars gevangen (al is een $1 \times 1 \mathrm{~m}$ net niet heel effectief om deze te vangen, zie Griffioen et al. 2014) 
De netmonitoring dat de vispassage/intrekvoorziening vangen:

- Aantallen succesvol passerende glasalen en driedoornige in de tijd (timing tijdens het voorjaar), en andere (kleine) vissoorten die intrekken

- Leveren glasalen en driedoornige stekelbaars die gemerkt kunnen worden met VIE tags voor lokale aanbodschatting

- Terugvangsten van bij de NWW gemerkte glasalen (aanbod totale intrek in NWW)

- Terugvangsten van lokaal gemerkte glasalen en driedoornige stekelbaars (lokale aanbod schatting)

- Terugvangsten van glasalen en driedoornige stekelbaars gemerkt bij andere intreklocaties (zoekgedrag tussen locaties)

- Verblijftijd van glasaal en driedoornige stekelbaars bij de intreklocatie

- Intrek-efficiëntie van de vispassage/intrekvoorziening

- Plus inzicht in passage van andere soorten

In figuur 5.1.1. is een schematisch overzicht van de voorgestelde opzet, aanpak en methodiek voor het intrekonderzoek weergegeven.

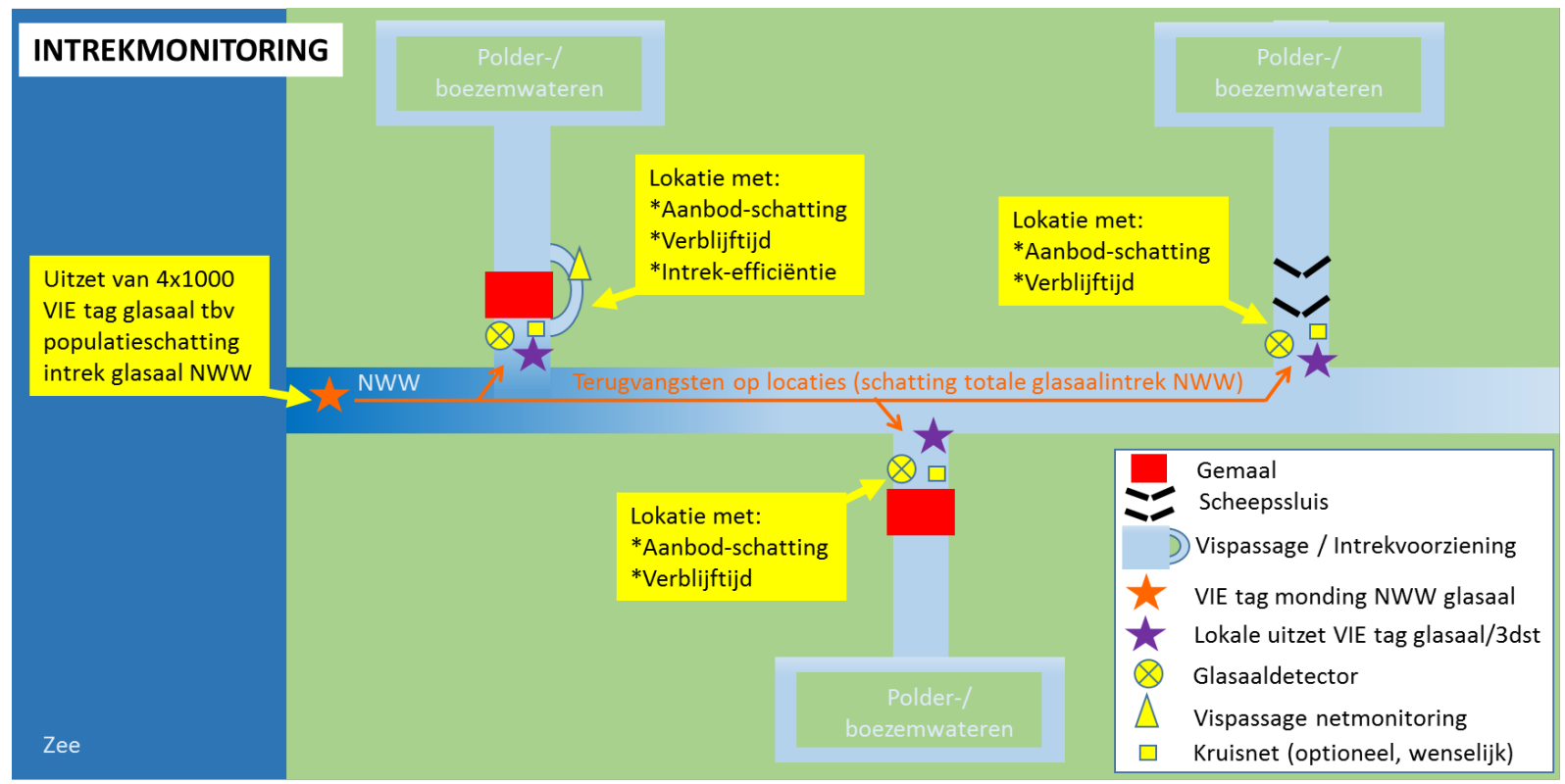

Figuur 5.1.1. Schematisch overzicht van de opzet van het voorgestelde intrekonderzoek naar glasaal en op een deel van de locaties ook driedoornige stekelbaars.

\subsection{Voorstel opzet monitoring uittrek}

Voor het uittrek-onderzoek worden groepen schieraal uitgerust met VEMCO V9 zenders. Deze schieralen worden gevangen aan de binnenzijde van de geselecteerde uittreklocaties (knooppunten) met fuiken in samenwerking met lokale beroepsvissers, of indien die niet beschikbaar zijn bijvoorbeeld door Visserij Service Nederland. Per vangst \& uitzet-locatie worden 25 schieralen gezenderd en uitgezet (verdeeld over 2 groepen om enige spreiding in tijd te krijgen) bij voorkeur op enkele kilometers afstand (indien niet mogelijk dichterbij) van de geselecteerde uitreklocatie.

Daarnaast wordt er een tijdelijk netwerk aan VEMCO detectiestations geïnstalleerd om de groepen uitgezette schieralen te kunnen volgen tijdens het uittrekken naar zee. Dit netwerk kan worden ingedeeld in een basisnetwerk die de grotere (meest rijkswateren) wateren in de Nieuwe Waterweg regio afdekken, en een aanvullend netwerk per uittrektreklocatie. Dit bestaat per uittreklocatie in principe uit drie ontvangststations, twee aan de binnenzijde aan weerszijden van de uitzetlocatie van de gezenderde schieralen (om te bepalen welke schieralen proberen te passeren, en welke eventueel terug de polder/boezem intrekken), en één aan de buitenzijde van het knooppunt (om percentage dat 
passeert te bepalen). Sommige meer complexe uittrekpunten met meerdere uittrekroutes/kunstwerken kunnen nog 1 of 2 extra detectiestations vergen om ook de uittrekroute te kunnen bepalen. Hiermee kan worden bepaald wanneer en hoe lang schieralen bij het uittrekpunt verblijven/zoeken, welk deel hier aankomt (attractie-efficiëntie) en eventueel welke schieralen verder de polder-/boezemwateren inzwemmen en wellicht via andere niet afgedekte uittreklocaties wegtrekt (kunnen dan wel vervolgens wel weer gedetecteerd worden in het basis-netwerk).

In figuur 5.2.1. is een schematisch overzicht van de voorgestelde opzet, aanpak en methodiek voor het uittrekonderzoek weergegeven.

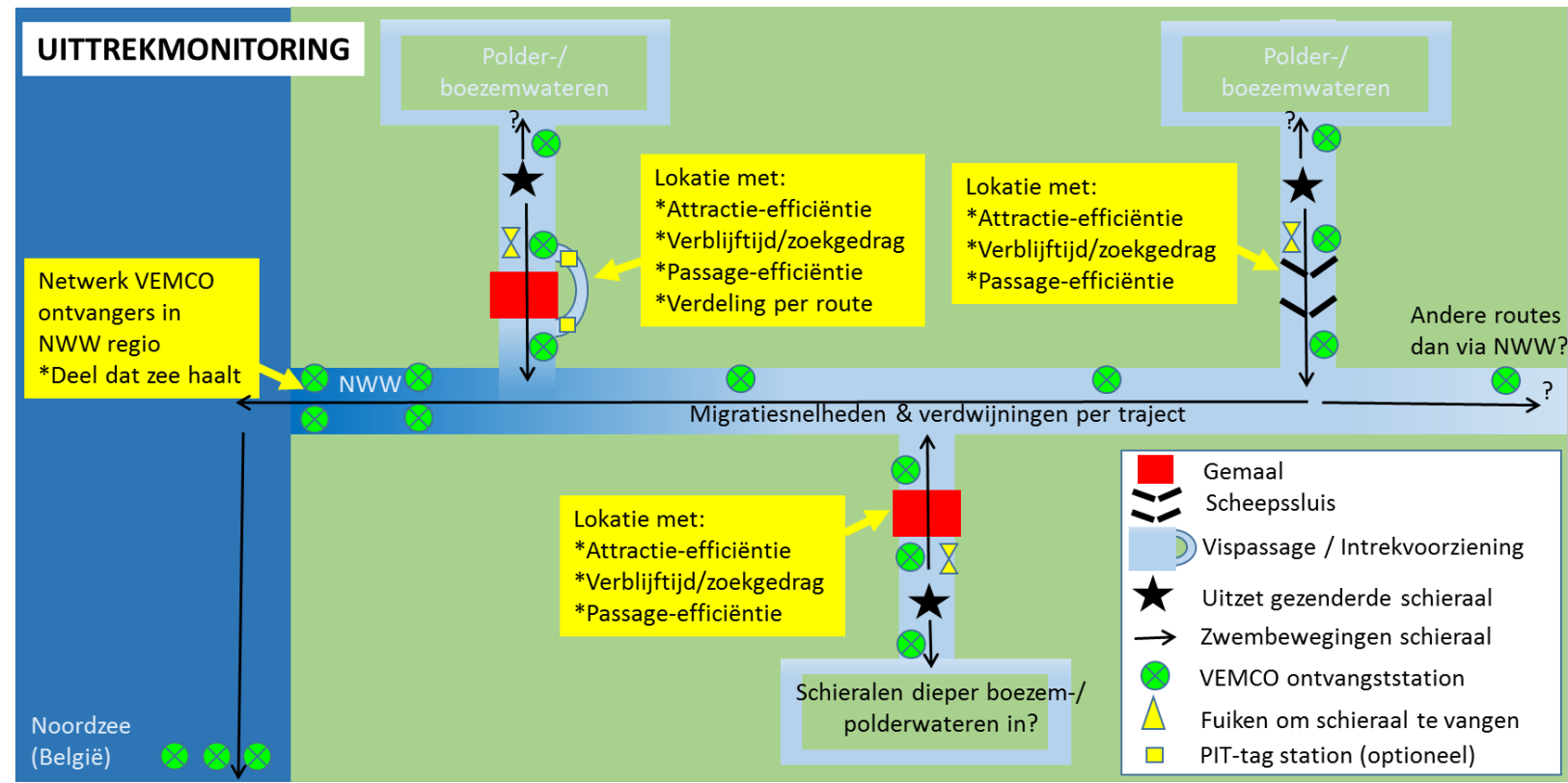

Figuur 5.2.1. Schematisch overzicht van de opzet van het voorgestelde uittrekonderzoek naar schieraal.

Het basis-netwerk moet in ieder geval de uitgang van de Nieuwe Waterweg, Hartelkanaal en alternatieve routes naar het Haringvliet, zoals Spui en Noord afdekken. Ook moeten de stroomopwaartse uittrekmogelijkheden in Hollandse IJssel, Lek en Beneden Merwede worden afgedekt. Op deze wijze is het kerngebied van de NWW regio waarbinnen de uittreklocaties geselecteerd worden, afgedekt. De voorgestelde opzet, aanpak en methodiek voor het uittrekonderzoek weergegeven in figuur 5.2.1.

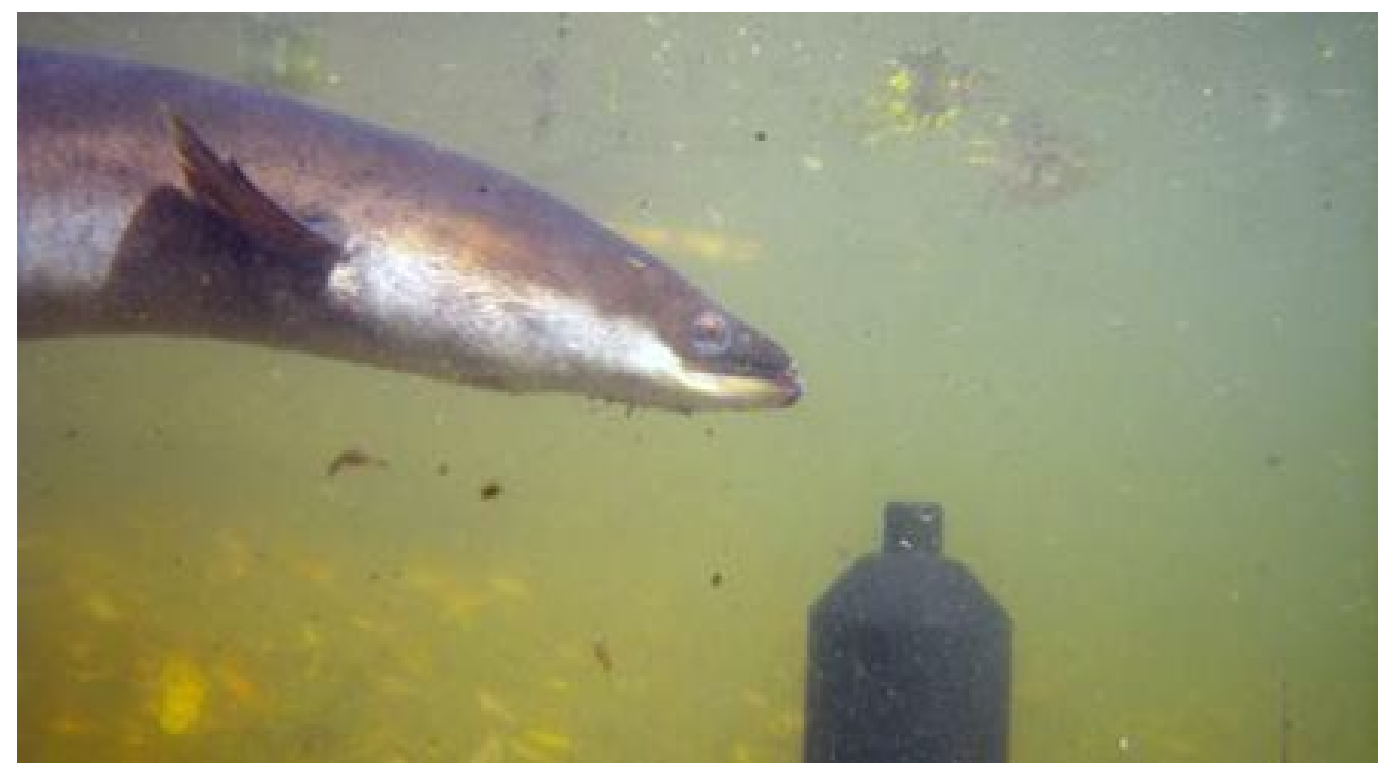

Gezenderde schieraal zwemt langs Vemco ontvanger (foto Erwin Winter) 


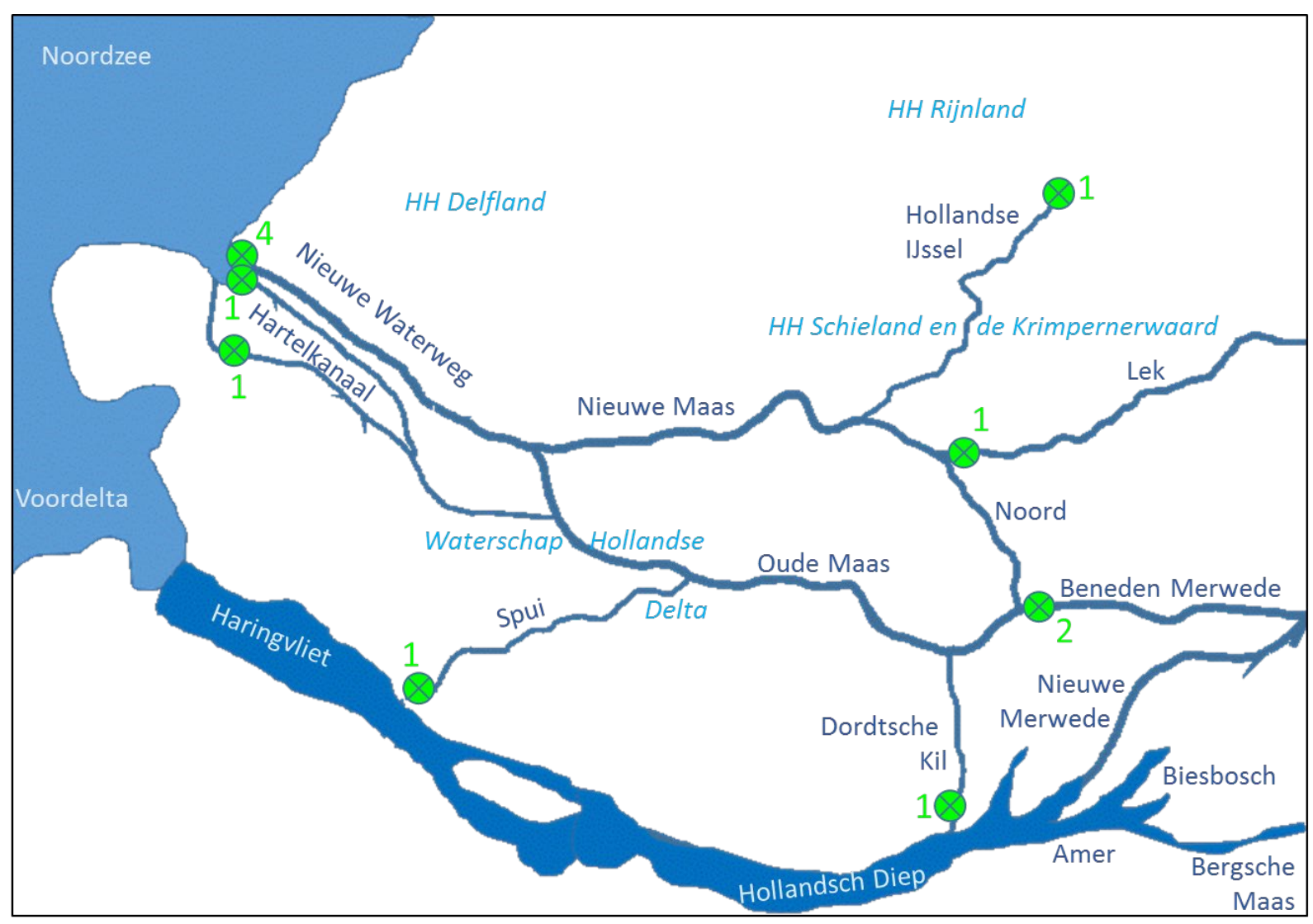

Figuur 5.2.2. Overzicht van de opzet van het voorgestelde basisnetwerk aan detectiestations voor de uittrek van schieraal. Binnen dit gebied wordt bij elk van de geselecteerde uittreklocaties nog minimaal 3 detectiestations geplaatst. Locaties van detectiestations zijn met $\varnothing$ weergegeven, het getal ernaast vermeld het aantal detectiestations.

\subsection{Relatie met ander lopend onderzoek \& monitoring}

Het voorgestelde intrek- en uittrekonderzoek kan aan zeggingskracht winnen of effectiever worden door deze aan andere onderzoeken of lopende monitoringen te linken, zo als bijvoorbeeld:

De invloed van sommige menselijke activiteiten zoals scheepvaart is zeer moeilijk rechtstreeks te meten. Door de migratiesnelheden en verdwijningspercentages van de NWW studie te vergelijken met migratiesnelheden en verdwijningspercentages over vrij stromende trajecten in de vele andere zenderstudies die inmiddels voor schieraal zijn uitgevoerd in de Maas, Rijn, Noordzeekanaal, Eemskanaal, Eems, Schelde, IJzer, Albertkanaal, kan er een indicatie worden verkregen over de mogelijke impact van scheepvaart. Binnen het European Tracking Network is een meta-analyse gestart naar de vele zenderonderzoeken die in verschillende Europese watersystemen worden uitgevoerd.

RAVON voert in samenwerking met vrijwilligers op een groot aantal locaties kruisnet-monitoringen uit (zie projectgroep Samen voor de Aal 2015, - 2018). Deze zijn een zeer waardevolle aanvulling op het voorgestelde onderzoek. Uiteraard op de geselecteerde locaties waar deze in aanvulling extra metingen voor timing, terugvangsten van gemerkte glasalen en driedoornige stekelbars opleveren. Ook kan de aanbodschatting worden gekoppeld aan de kruisnet- en glasaaldetectoren vangsten zodat ook voor andere jaren het onderliggende aanbod glasaal per trekseizoen kan worden berekend.

Verder vindt er de komende jaren onderzoek met glasaaldetectoren, kruisnetten en VIE tagging van glasaal plaats door WMR in opdracht van LNV op een vijftal locaties langs de Nederlandse kust; Stellendam, Katwijk, IJmuiden, Den Oever, Nieuw-Statenzijl. De gebruikte kleurcodes zouden hierbij moeten worden afgestemd zodat elke locatie/groep een unieke kleurcode heeft (of indien dit niet 
mogelijk is, dezelfde kleurcodes alleen bij ver van elkaar gelegen punten worden gebruikt) en er ook eventuele grootschalige bewegingen van glasaal gedetecteerd kunnen worden.

In het kader van de Kier in het Haringvliet (Griffioen et al. 2017) zal de komende jaren visonderzoek plaats vinden. Eventueel telemetrie-onderzoek (zoals beoogd voor jonge steur) in en rond het Haringvliet kan een goede uitbreiding van het VEMCO netwerk betekenen waarmee ook vervolgmigraties van schieralen die alternatieve routes nemen beter kan worden gevolgd.

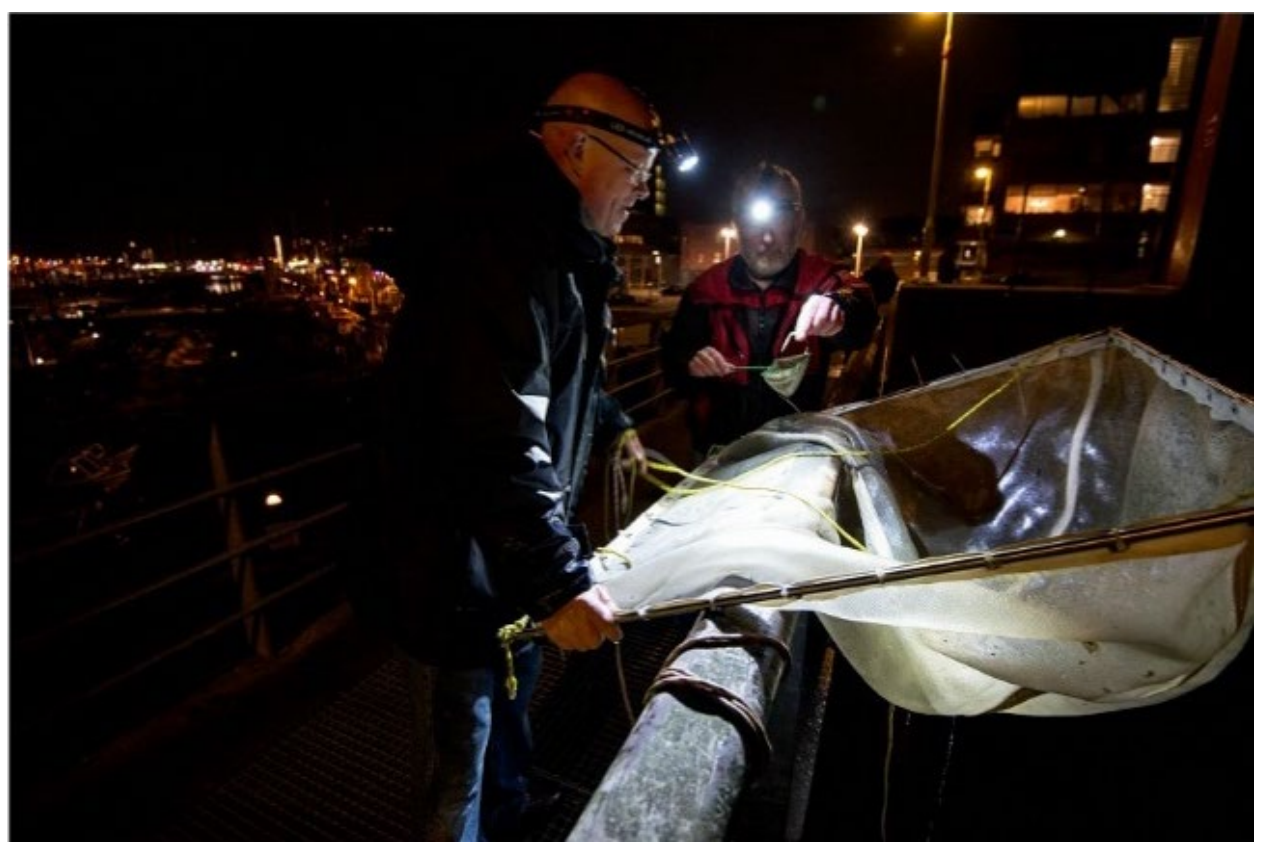

Kruisnetbemonsteringen met vrijwilligers (foto RAVON)

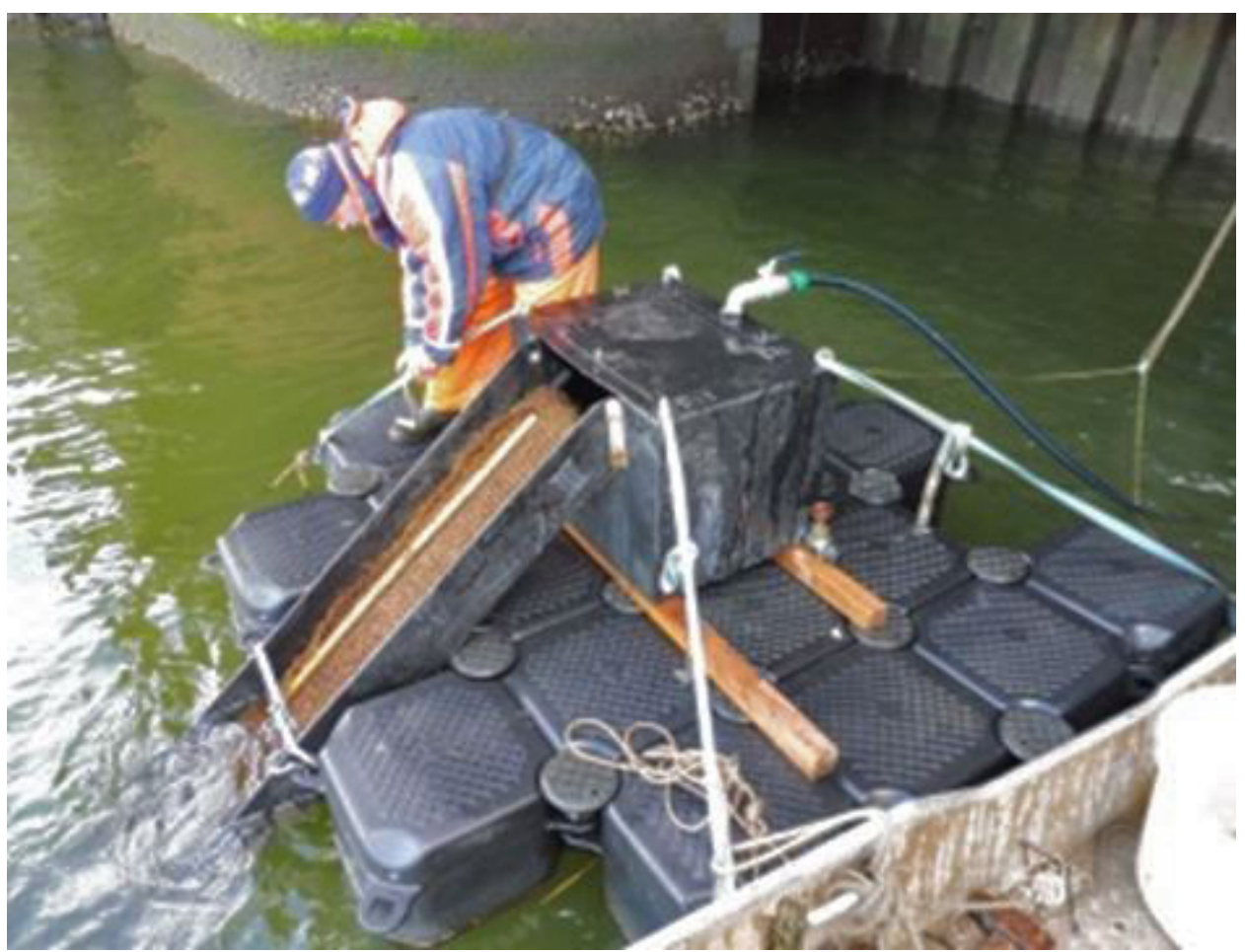

Glasaal detector, met kokosmat helling met lokstroom en opvangbassin (foto Ben Griffioen) 


\section{Aanbevelingen en overwegingen}

Met de voorbereiding en uitvoering van de voorgestelde monitoringen kan met het volgende aanbevelingen en overwegingen rekening worden gehouden:

- Voor de plaatsing van VEMCO ontvangers zal tijdig medewerking meten worden gezocht met de lokale waterbeheerder en de praktische mogelijkheden worden besproken, soms is ontheffing op de waterwet en havendienst. Dit kan soms tijdrovend zijn.

- Voor het uitvoeren van de merk- en zender experimenten is een vergunning en goedgekeurd plan voor de Wet Op Dierexperimenten nodig. Deze procedures kunnen soms maanden duren.

- Goede voorlichting aan vrijwilligers van de kruisnetbemonstering i.s.m. RAVON over VIE tags, plus uitrusten met UV lamp, vergroot de kansen op terugvangsten en bruikbaarheid binnen dit monitoringsplan.

- Het betrekken van het havenbedrijf in de Rijnmond bij de onderzoeken.

- Rijkswaterstaat West Nederland Noord heeft voor het Noordzeekanaal onderzoek (Winter et al. 2019) 10 VEMCO detectiestations aangeschaft. Deze kunnen op aanvraag waarschijnlijk ook ingezet worden in het NWW onderzoek. Verder zijn er inmiddels vele instituten, onderzoeksbureaus en organisaties die VEMCO ontvangers in bezit hebben, waaronder Sportvisserij Nederland (heeft het grootste aantal ontvangers in Nederland), Wageningen Marien Research, ATKB, Visadvies, VLIZ (België). Het loont om voor aanvang bij elk van deze partijen te informeren of er ontvangers 'vrij' beschikbaar zijn die tijdelijk niet voor andere projecten worden gebruikt en welk onderzoekjaar dan het beste gekozen kan worden. Dit kan de kosten van het NWW netwerk verder reduceren.

- Er vindt via Life-IP een regionale PIT tag studie in boezem-KRW water plaats bij HDSR. Eventueel aangeschafte apparatuur voor PIT tagging kan bij keuze voor PIT tagging op een specifieke locatie wellicht binnen Rijn-West verband worden ingezet.

- Visserij Service Nederland is ook bezig met het ontwikkelen van een collector voor driedoornige stekelbaars. Indien beschikbaar is deze zeker het overwegen waard op sommige intrek-locaties. 


\section{Kwaliteitsborging}

Wageningen Marine Research beschikt over een ISO 9001:2015 gecertificeerd kwaliteitsmanagementsysteem. Dit certificaat is geldig tot 15 december 2021. De organisatie is gecertificeerd sinds 27 februari 2001. De certificering is uitgevoerd door DNV GL. 


\section{Literatuur}

Brevé N. W. P., H. Vis, B. Houben, A. Breukelaar \& M. L. Acolas, 2018. Outmigration pathways of stocked juvenile European sturgeon (Acipenser sturio L., 1758) in the Lower Rhine River, as revealed by telemetry. Journal of Applied Ichthyology

De Bruijne, W., Vriese, T., Kampen J., Rutjes P., 2017. Vismigratie Zuid Hollandse sluizen: Onderzoek naar de vispasseerbaarheid van vijf schutsluizen in Zuid Holland; Julianasluis Gouda, Sluis Bodegraven, Grote Merwedesluis, Vianen grote sluis en schutsluis Leidschendam. LINKit Consult \& ATKB rapport.

Griffioen $A B$, Winter $H V$, van Hal R, 2017. Prognose visstand in en rond het Haringvliet na invoering van het Kierbesluit in 2018. Wageningen University \& Research Rapport C081/17.

Griffioen $A B$, Winter HV (2017). Fish migration river monitoring plan: Monitoring program on the effectiveness of the FMR at Kornwerderzand. IJmuiden: Wageningen Marine Research, (Wageningen Marine Research report C012/17A) - 50 p.

Griffioen, A. B., M. E. Schiphouwer, H. V. Winter, and S. Ploegaert. 2018 Aalonderzoeken Hoogheemraadschap van Delfland: efficiëntie van glasaalintrek bij gemaal Schoute Wageningen Marine Research report C007.18.

Griffioen, A. B., and H. V. Winter. 2018. Glasaal bij het sluiscomplex van IJmuiden - Een pilotstudie ter voorbereiding van een onderzoek naar het gedrag, voorkomen en passage van glasaal bij het sluiscomplex te IJmuiden., Wageningen University \& Research rapport C001/18.

Griffioen, A. B., H. V. Winter, O. A. v. Keeken, and B. v. Houten. 2019. Intrek van glasaal en driedoornige stekelbaars in het Noordzeekanaal voorjaar 2018. Wageningen Marine Research rapport C054/19.

Hees, J. van \& Peters, H. (redactie), 1998. MER Beheer Haringvlietsluizen: Over de grens van zout en zoet. Deelrapport Water- en Zoutbeweging. ISBN: 903694871. RWS, notanummer: apv 98/093.

Projectgroep Samen voor de Aal, 2015. Samen voor de Aal; Kruisnetmonitoring Zuidwestelijke Delta 2015 (datarapportage). Projectnummer 2015.031. Stichting RAVON, Nijmegen.

Projectgroep Samen voor de Aal, 2019. Samen voor de Aal; Kruisnetmonitoring Zuid-Holland resultaten en analyse 2015-2018. Projectnummer 2015.031. Stichting RAVON, Nijmegen.

Spier, J.L., M. Japink, P.B. Broeckx \& J.H. Bergsma, 2016. Vismigratieplan. Waterschap Hollandse Delta. Bureau Waardenburg Rapportnr. 16I093. Bureau Waardenburg, Culemborg.

Jansen, H.M., H.V. Winter, M.C.M. Bruijs \& H. Polman (2007). Just go with the flow? Route selection and mortality during downstream migration of silver eels in relation to discharge. ICES Journal of marine Science 64: 1437-1443.

Van Keeken OA, Winter HV, Griffioen AB, de Graaf M, (2013). Silver eel behaviour in the vicinity of pumping stations: a telemetry study in Friesland. IMARES-report C120/13.

Verhelst P, Bruneel S, Reubens J, Coeck J, Goethals P, Oldoni D, Moens T, Mouton A. 2018a. Selective tidal stream transport in silver European eel (Anguilla anguilla L.)-migration behaviour in a dynamic estuary. Estuarine, Coastal and Shelf Science 213:260-268

Verhelst P., R. Baeyens, J. Reubens, J.-P. Benitez, J. Coeck, P. Goethals, M. Ovidio, J. Vergeynst, T. Moens, A. Mouton (2018b). European silver eel (Anguilla anguilla L.) migration behaviour in a highly regulated shipping canal. Fish. Res., 206 (2018), pp. 176-184

Verhelst P., D. Buysse, J. Reubens, I. Pauwels, B. Aelterman, S. Van Hoey, P. Goethals, J. Coeck, T. Moens, A. Mouton (2018c). Downstream migration of European eel (Anguilla anguilla) in an anthropogenically regulated freshwater system: implications for management. Fish. Res., 199 (2018), pp. 252-262

Verhelst P., J. Reubens, I. Pauwels, D. Buysse, B. Aelterman, S. Hoey, P. Goethals, T. Moens, J. Coeck, A. Mouton (2018d). Movement behaviour of large female yellow European eel (Anguilla anguilla L.) in a freshwater polder area. Ecol. Freshw. Fish, 27 (2018), pp. 471-480

Winter, H.V., H.M. Jansen \& A.W. Breukelaar (2007). Silver eel mortality during downstream migration in the River Meuse, a population perspective. ICES Journal of marine Science 64: 1444-1449 . 
Winter, H.V., Jansen, H.M. \& Bruijs, M.C.M. (2006). Assessing the impact of hydropower and fisheries on downstream migrating silver eel, Anguilla anguilla, by telemetry in the River Meuse. Ecology of Freshwater Fish 15: 221-228.

Winter HV, van Keeken OA, Brockötter J, Griffioen AB (2019). Migratiepatronen en -knelpunten tijdens uittrek van schieraal uit Noorzeekanaal en ommelanden, inclusief Markermeer: Onderzoek met akoestische telemetrie en PIT-tags 2017-2018: eindrapport. Wageningen Marine Research Report C053/19. 


\section{Verantwoording}

Rapport C128/19

Projectnummer: 4316100195

Dit rapport is met grote zorgvuldigheid tot stand gekomen. De wetenschappelijke kwaliteit is intern getoetst door een collega-onderzoeker en het verantwoordelijk lid van het managementteam van Wageningen Marine Research

Akkoord:

Dr. P. de Bruijn

DLO-onderzoeker

Handtekening:

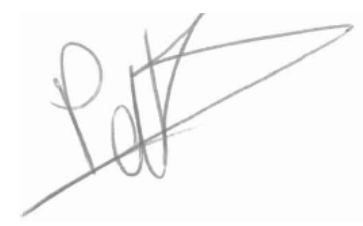

Datum:

13-12-2019

Akkoord:

drs. J. Asjes

MT-Directie

Handtekening:

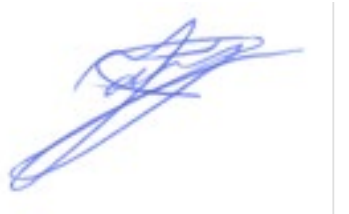

Datum:

13-12-2019 


\section{Bijlage 1 Samenwerkingsverklaring}

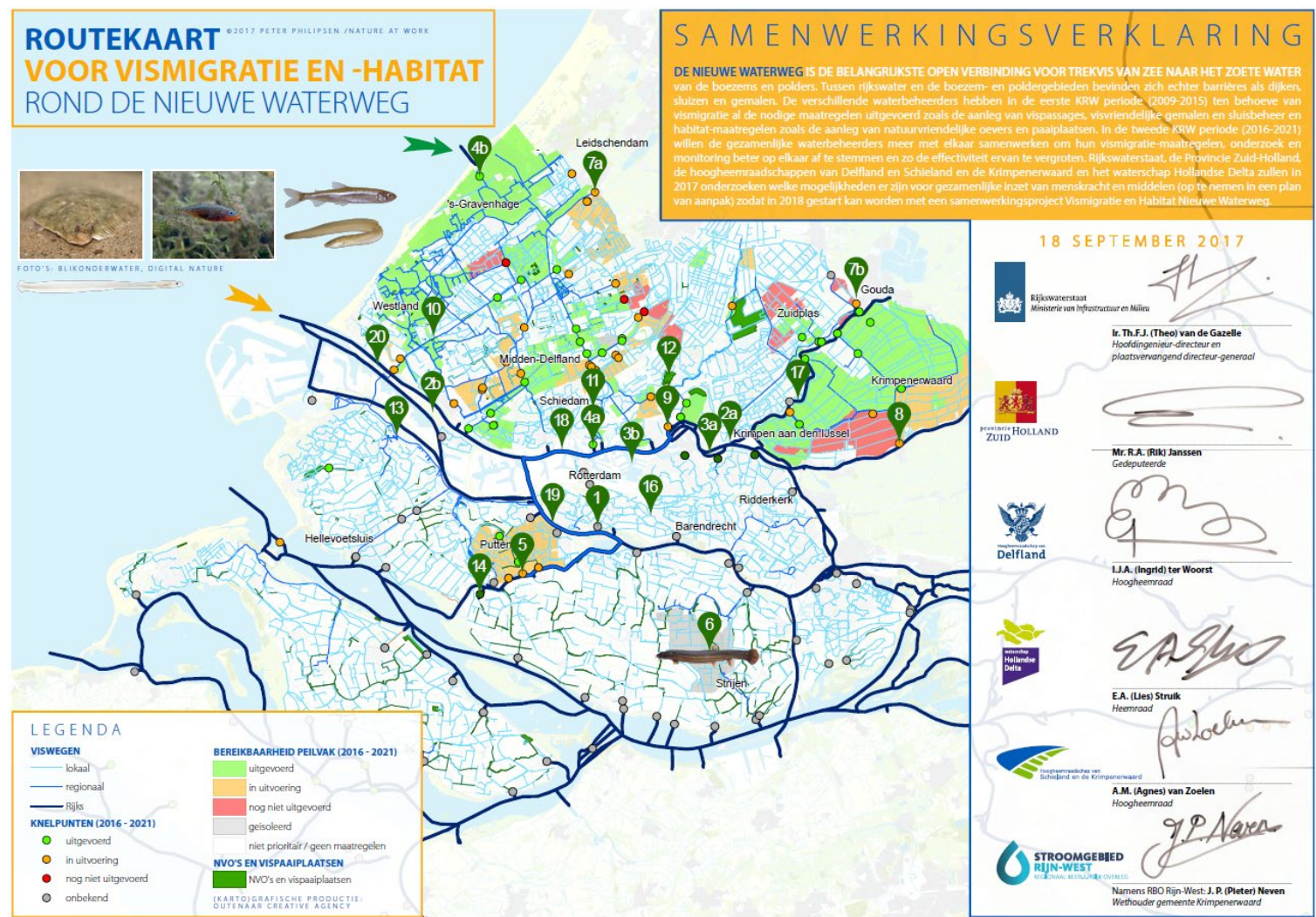




\section{Bijlage 2 Inventarisatie beheersvragen en locaties (in- en uittrek-knooppunten)}

Voor elk van de waterbeheerders en de provincie Zuid-Holland zijn werksessies belegd om de beheersvragen met betrekking tot vismigratie tussen achterland (boezem- en poldersystemen), rijkswateren en zee te inventariseren. Hieronder wordt een beknopt overzicht gegeven van de voerwegingen en beheersvragen die daarbij naar voren kwamen per beheersgebied:

\section{Rijkswateren in Nieuwe Waterweg regio:}

- $\quad$ Niet fysieke barrières: invloed van verstoring, scheepvaart.

- $\quad$ Verschil in uittrek tussen Nieuwe Waterweg en Haringvliet, op grotere schaal.

- $\quad$ Aanbod bij rijks regio knooppunten zijn die goed doortrekbaar zijn.

- $\quad$ In hoeverre rijkswater in NWW regio ook habitat zijn voor langer verblijf van trekvis.

- $\quad$ Bij intrek hoe lopen keuzes tussen zijwegen en nieuwe waterweg.

- $\quad$ Hoe verdeelt de vis zich zowel van intrek: glasaal, driedoornige stekelbaars.

- Vergelijkbaarheid met Noordzeekanaal als randvoorwaarde: zowel intrek als uittrek.

- $\quad$ Combinatie met RAVON: goed grotere netwerk Samen voor de aal, bij onderzoek betrekken.

- $\quad$ Opnieuw kijken naar prioriteiten Rijksregio-overgangen 2016-2021.

- $\quad$ Focus m'n op Oude Maas/ Spui i.v.m. resultaat onderzoek Bob Slagter en grotere kansen daar.

Hoe is visaanbod verdeeld over NWW $(+\mathrm{HV})$, bij Rijksregio-overgangen of verderop in systeem? Hoeveel procent aanbod glasaal NWW/HV gaat polders in en hoeveel zwemt rivier op? Verdeling glasaal lijkt groter te zijn richting Oude Maas i.v.m. debiet, maar moet verder onderzocht/bevestigd worden.

- $\quad$ I.v.m. open systeem: ratio kruisnet/ glasaalcollector per knooppunt weten. Rekenfactor meerjarige kruisnetmetingen

\section{Hoogheemraadschap Schieland:}

- $\quad$ Uittrek: extra maal events tussen natuurlijke maalevent door om uittrek te faciliteren: is dit noodzakelijk/geeft dit meerwaarde (testen met gezenderde schieraal)?

- Gemaal Schilthuis, (zie rapport W+B Kruitwagen) is grootste debiet, en ook inlaatpunt (inlaatregime protocol), intrek is ook ingeregeld na even aanzetten pomp om leiding vol te zetten, mogelijk af te dichten met netwerk?

- $\quad$ Uittrek Schilthuis: eerder onderzoek met schade aan vis in gemalen (jouke en wilkin). Schade $20 \%$, type pomp pompregime, testen bediening + optimaliseren beheer?

- Gemaal Verdoold, nieuw, heeft visvriendelijke axiaalpomp, is getest met NEN dierproef, optionele locatie voor testen met gezenderde schieraal om werkelijke visvriendelijke uittrek (incl. eventueel barrière-werking te testen),

- $\quad$ Intrek bij gemaal Verdoold, met kruisnet Wilkin de Boer en W+B. Intrekvoorziening via de pomp inlaten, geen scheepssluis: Gerard Manshanden heeft frame? Hele natte oppervlakte doormeten? Of steekproefsgewijs met driftnetten? Ter plaatste is $2 \mathrm{~m}$ getijdeverschil; intrekvenster regime nu. Optimalisatie van dit inlaatregime: timing en bediening t.o.v. getijde en dag nacht belang?

- $\quad$ Intrek als optie bij gemaal Abraham Kroes (hevelvispassage) en snelle sluis (inlaat) staat bijna elke dag aan: bemonstering met fuik in 2012.

- Gemaal Krimpernerwaard gemaal is zeer schadelijk, in 2021 waarschijnlijk visvriendelijk gemaakt (wellicht optioneel?)?

Prioritering intrek: Gemaal Schilthuis (1, basis), Gemaal Verdoold (1, basis) en eventueel Snellesluis/ringvaart Kroes (optioneel)

Prioritering uittrek: Gemaal Schilthuis (1, basis), Gemaal Verdoold (2, optioneel) en eventueel Snellesluis/ringvaart Kroes (optioneel) 


\section{Waterschap Hollandse Delta:}

- $\quad$ Heel versnipperd beheersgebied met 140 overgangen met rijkswater en vele gemalen

- $\quad$ Gemalen Hogenesse (hier is glasaal detector onderzoek geweest, hier aanbodschatting?

- $\quad$ Gemaal Breeman, zuidkant hoekse ward (visvriendelijk)?

- $\quad$ Gemaal Putten aan het spui: sinds 2018 is deze vispasseerbaar gemaakt. Evalueren of deze zowel voor intrek van glasaal en driedoornige stekelbaars als voor uittrek van schieraal goed functioneert?

- $\quad$ Glasaal intrek via de Zuiderdiepboezem, Spuisluis Rozenburg Voorne naar Brielse Meer en uittrek schieraal via Hartelkanaal? Brielse Meer systeem en kanaal hebben aparte inlaat, uitmalen via gemaal op kanaal en dan via sluis en gemaal naar Haringvliet.

- $\quad$ In de Nieuwe waterweg zijn de eerste intrek en uittreklocaties gelegen in de Oude Maas (gemaal Breeman, gemaal Hoogenesse, zijn de twee grootste gemalen)

- Voorne Putten kent ingewikkelde situatie voor vis, deels via Putten, gemalen Noordermeer en met name door gemaal Putten.

- Gemaal Komstrijen, is ook inlaatwerk. Na malen nog een tijd laten inmalen; potentieel interessant voor intrek, maar hebben schieralen ook voldoende uittrekmogelijkheden? Achterland is intern enorm verdeeld in peilgebieden.

- Gemaal Bonaventura als intrek, aanbodlocatie?

- Prioritering intrek: Gemaal Putten (1, basis), Spuisluis Voorne alleen aanbod en verblijftijd (2, optioneel) en eventueel gemaal Bonavetura, gemaal Breeman en/of gemaal Hoogenesse (3, optioneel)

- $\quad$ Prioritering uittrek: Gemaal Putten (1, basis), vanuit Brielse Meer (2, optioneel)

\section{Hoogheemraadschap Delfland:}

- $\quad$ Bij gemaal Schouten gaat in 2020 een aangepast regime in operatie (wellicht testen voor intrek)?

- $\quad$ Gemaal Schouten, uittrek schieraal nog onbekend?

- $\quad$ Lozing Houtrust op zee (ook aantrekkingskracht op glasaal); Vd Burg (Westland, jaarrond $1 \mathrm{~m}^{3} / \mathrm{min}$, is nu een doodlopende steeg (er zijn aanwijzingen voor glasaal ophoping)

- Gemaal Krimsloot: opmalingspoldertje: klein debiet, klein achterland van slechte habitatkwaliteit; geen prioriteit.

Effluentlozing RWZI Nieuwe Waterweg, wellicht attractief voor glasaal, maar lastig passage te maken?

Gemaal Westland: zowel lozen van water, als inlaat inpompen vanuit Brielse meer: intrekvoorziening (nog nooit getest)?

Maassluis (de sluizen daar niet in beheer van waterschap): binnenhaven: Monsterse Sluis net gerenoveerd, vereniging wil ook graag meewerken om glasaal in te laten trekken via sluisbeheer, direct daarna Wateringse sluis (spuisluis) nu alleen pompje om lekwater terug te pompen: glasaal aanbod: kruisnet metingen samen voor aal.

Gemaal Zaaijer: belangrijk gemaal, pompt meeste water uit: intrekvoorziening via de spuikoker gemaakt (2012, 2014 aan gemeten), Beveron/schroefcentrifugaal pompen en 2 kattenruggen; schade onderzoek gedaan aan schieraal: viswerende constructies geprobeerd met weinig succes.

- $\quad$ Rwzi de Grote Lucht (VSN bijna geen glasaal): geen kom, direct op NWW erg dynamisch

- $\quad$ Vlaardingen Wets: klein poldergemaaltje, enorm lange leiding

- Vlaardingen (driesluizen): sluis plus pompje: samen voor de aal

- $\quad$ Schiedam: kleine kom: intrekvoorziening via de spuikoker: metingen aan verricht; kruisnet vrijwel geen vangsten; intrek in achterland

- $\quad$ Schiegemaal: kan inlaten uitmalen, klein kommetje maar wel via kokers, afsluitbaar naar zijhaven; weinig effectieve vispassage nu:

- $\quad$ Gemaal Parksluizen, maalt regelmatig uit + 2 schutsluizen beroeps- en recreatief; wanneer er veel zout naar binnen komt dan wordt via Parksluizen weer uitgemalen: glasaalcollector gemeten ( 0 glasaal gevangen) 


\section{Intrekvragen HHvD:}

- Wat komt er bij Gemaal Westland binnen: wat is het aanbod; wat is huidige intreksucces: is wel bemonsterbaar (Wilkin is ooit opdracht gegeven om een net hier te maken, maar of dit er nog is?): 1e goed merkbare lokstroom op NWW.

- $\quad$ Gemaal Zaaijer: frame is er al; in 2012 en 2014 gemonitord, opvangnet in sponningen; steekproefsgewijs te bemonsteren (geen continue meting mogelijk)

- Schiegemaal zowel aanbod als intrek-efficiëntie'; intrekvoorziening is monitoorbaar: is frame met fuik voor gemaakt 2014 (de vraag is deze er nog? Met opzetstuk)

- Optioneel: Wateringsluizen: alleen aanbod schatting

\section{Uittrekvragen HHvD:}

- Waar trekken de schieraal naar buiten: aanbodsschattingen en verdeling over de boezem

- $\quad$ Wat is de sterfte van schieraal bij de geselecteerde uittrekpunten?

- $\quad$ Debietsverdeling in relatie tot uittrek vans chieraal: gelijkmatig verdelen?

- Prioritering; gemaal Zaaijer (1, basis), gemaal Schouten (2, optioneel), Gemaal Westland (3, optioneel), gemaal Parksluizen (3, optioneel)

- Gemaal Zaaijer: 3 pompen: 4-5m x 4-5m per opening. Voor uittrek ook pit-tag opties, waarbij gemaal volledig is af te dekken?

\section{Provincie Zuid-Holland: Hoofdwatersysteem en provinciale sluizen}

- $\quad$ Provincie beheert alleen sluizen in het beheersgebied NWW regio:

- $\quad 5$ sluizen bij Vianen, Merwede/Gorkum, Bodegraven, Gouda, Leidschendam

- $\quad$ Er zijn inventarisatieonderzoeken geweest in sluizen, met name Gouda.

- $\quad$ Prioritering: Julianasluizen bij Gouda, wat kan worden gefinetuned voor het faciliteren van de uittrek van schieraal? Dit ook graag in samenwerking met stroomopwaarts gelegen Hoogheemraadschap van Rijnland

- $\quad$ Evaluatie dan wel gebruikmaking van Paling Over de Dijk in beheersgebied NWW regio. 
Wageningen Marine Research

T: +31(0)317480900

E: marine-research@wur.nl

www.wur.nl/marine-research

Bezoekers adres:

- Ankerpark 271781 AG Den Helder

- Korringaweg 7, 4401 NT Yerseke

- Haringkade 1, 1976 CP IJmuiden
Wageningen Marine Research levert met kennis, onafhankelijk wetenschappelijk onderzoek en advies een wezenlijke bijdrage aan een duurzamer, zorgvuldiger beheer, gebruik en bescherming van de natuurlijke rijkdommen in zee-, kust- en zoetwatergebieden.

Wageningen Marine Research is onderdeel van Wageningen University \& Research. Wageningen University \& Research is het samenwerkingsverband tussen Wageningen University en Stichting Wageningen Research en heeft als missie: 'To explore the potential of nature to improve the quality of life' 